\title{
THE EFFECTS OF MEGAMERGERS ON EFFICIENCY AND PRICES: EVIDENCE FROM A BANK PROFIT FUNCTION
}

\author{
Jalal D. Akhavein* \\ Department of Economics \\ New York University, New York, NY 10012 \\ and \\ Wharton Financial Institutions Center \\ University of Pennsylvania, Philadelphia, PA 19104 \\ Allen N. Berger* \\ Board of Governors of the Federal Reserve System \\ Washington, DC 20551 \\ and \\ Wharton Financial Institutions Center \\ University of Pennsylvania, Philadelphia, PA 19104 \\ David B. Humphrey* \\ F. W. Smith Eminent Scholar in Banking \\ Department of Finance \\ Florida State University, Tallahassee, FL 32306
}

Forthcoming, Review of Industrial Organization, Vol.12,1997

*The views expressed do not necessarily reflect those of the Board of Governors or its staff. The authors thank Anders Christensen for very useful discussant's comments, Bob DeYoung, Tim Hannan, Steve Pilloff, Steve Rhoades, and the participants in the Nordic Banking Research Seminar for helpful suggestions, and Joe Scalise for outstanding research assistance.

Please address correspondence to Allen N. Berger, Mail Stop 180, Federal Reserve Board, 20th and C Sts. N. W., Washington, DC 20551, call 202-452-2903, fax 202-452-5295 or -3819, or e-mail mlanb00@frb.gov. 


\title{
THE EFFECTS OF MEGAMERGERS ON EFFICIENCY AND PRICES: EVIDENCE FROM A BANK PROFIT FUNCTION
}

\begin{abstract}
$\underline{\text { ABSTRACT }}$
This paper examines the efficiency and price effects of mergers by applying a frontier profit function to data on bank 'megamergers'. We find that merged banks experience a statistically significant 16 percentage point average increase in profit efficiency rank relative to other large banks. Most of the improvement is from increasing revenues, including a shift in outputs from securities to loans, a higher-valued product. Improvements were greatest for the banks with the lowest efficiencies prior to merging, who therefore had the greatest capacity for improvement. By comparison, the effects on profits from merger-related changes in prices were found to be very small.
\end{abstract}

JEL Classification Codes: L11, L41, L89, G21, G28

Keywords: Bank, Merger, Efficiency, Profit, Price, Antitrust 


\section{THE EFFECTS OF MEGAMERGERS ON EFFICIENCY AND PRICES: EVIDENCE FROM A BANK PROFIT FUNCTION}

\section{Introduction}

The recent waves of large mergers and acquisitions in both manufacturing and service industries in the United States raise important questions concerning the public policy tradeoff between possible gains in operating efficiency versus possible social efficiency losses from a greater exercise of market power. If any improvements in operating efficiency from these mergers are large relative to any adverse effects of price changes created by increases in market power, then such mergers may be in the public interest. For an informed antitrust policy, it is also important to know if there are identifiable ex ante conditions that are good predictors of either efficiency improvements or increases in the use of market power in setting prices. Whether or not these mergers are socially beneficial on average, there may be identifiable circumstances that may help guide the policy decisions about individual mergers. Current antitrust policy relies heavily on the use of the ex ante Herfindahl index of concentration for predicting market power problems and considers operating efficiency only under limited circumstances. ${ }^{1}$

The answers to these policy questions largely depend upon the source of increased operating profits (if any) from consolidation. Mergers and acquisitions could raise profits in any of three major ways. First, they could improve cost efficiency, reducing costs per unit of output for a given set of output quantities and input prices. Indeed, consultants and managers have often justified large mergers on the basis of expected cost efficiency gains.

Second, mergers may increase profits through improvements in profit efficiency that involve superior combinations of inputs and outputs. Profit efficiency is a more inclusive concept than cost efficiency, because it takes into account the cost and revenue effects of the choice of the output vector, which is taken as given in the measurement of cost efficiency. Thus, a merger could improve profit efficiency without improving cost efficiency if the reconfiguration of outputs associated with the merger

${ }^{1}$ See U.S. Department of Justice and Federal Trade Commission (1992). 
increases revenues more than it increases costs, or if it reduces costs more than it reduces revenues. We argue below that analysis of profit efficiency is more appropriate for the evaluation of mergers than cost efficiency because outputs typically do change substantially subsequent to a merger.

Third, mergers may improve profits through the exercise of additional market power in setting prices. An increase in market concentration or market share may allow the consolidated firm to charge higher rates for the goods or services it produces, raising profits by extracting more surplus from consumers, without any improvement in efficiency.

These policy issues are of particular importance in the banking industry because recent regulatory changes have made possible many mergers among very large banks. The 1980s witnessed the beginning of a trend toward 'megamergers' in the U.S. banking industry, mergers and acquisitions in which both banking organizations have more than $\$ 1$ billion in assets. This trend -- which was precipitated by the removal of many intrastate and interstate geographic restrictions on bank branching and holding company affiliation -- has continued into the 1990s. At the outset of the 1980 s, only $2.1 \%$ of bank assets were controlled by out-of-state banking organizations. Halfway through the 1990s, $27.9 \%$ of assets were controlled by out-of-state bank holding companies, primarily through regional compacts among nearby states. ${ }^{2}$ The Riegle-Neal Interstate Banking and Branching Efficiency Act of 1994 is likely to accelerate these trends, since it allows bank holding companies to acquire banks in any other state as of September 29,1995, and will allow interstate branching in almost every state by June 1,1997.

There are other reasons why banking provides such an interesting academic and policy experiment for mergers. First, competition in banking has been restricted for a long time by geographic and other restrictions, so inefficiencies might be expected to persist. The market for corporate control in banking has also been quite limited, since nonbanks are prohibited from taking over banks, and the geographic barriers to competition have also reduced the potential for takeovers by more efficient banks. These

${ }^{2}$ See Berger, Kashyap, and Scalise (1995). 
restrictions on competition both in the product markets and in the market for corporate control may have protected inefficient managers. Both types of restrictions are now being lifted.

Second, the banking industry has relatively clean, detailed data available from regulatory reports that give information on relatively homogeneous products in different local markets with various market structures and economic conditions. This makes for an almost ideal controlled environment in which to test various industrial organization theories. As a result, banking is one of the most heavily researched industries in industrial organization, yielding a relatively strong background literature upon which to build.

Unfortunately, the academic literature has made jittle progress in determining source of profitability gains, if any, associated with bank mergers. of the three main sources of potential profitability gains from mergers, the literature has focused primarily on cost efficiency improvements. As discussed below, the empirical evidence suggests that mergers have had very little effect on cost efficiency on average. Moreover, there has also been little progress in divining any ex ante conditions that accurately predict the changes in cost efficiency that do occur for possible use in antitrust policy.

Despite the advantages of the profit efficiency concept over cost efficiency, we are not aware of any previous studies in banking or any other industry of the profit efficiency effects of mergers. Although many studies have examined changes in some profitability ratios pursuant to mergers, such studies cannot determine the extent to which any increase in profitability is due to an improvement in profit efficiency (which is a change in quantities for given prices) versus an increase in market power (a change in price for a given efficiency level).

Similarly, there are very few academic studies of which we are aware of the changes in prices associated with bank mergers. Price changes would reveal the effects of increases in market power plus any price effects that may result from changes in operating efficiency. The lack of analysis of the market power effects of bank mergers is perhaps surprising given that a major thrust of current antitrust 
enforcement is to prevent mergers which are expected to result in prices less favorable to consumers (higher loan rates, lower deposit rates) or to require divestitures that accomplish this goal.

The purpose of this paper is to add some of the missing information about the profit efficiency and market power effects of mergers. We analyze data on bank megamergers of the $1980 \mathrm{~s}$, using the same data set as employed in an earlier cost efficiency analysis (Berger and Humphrey 1992). In this way, all three of the potential sources of increased operating profits from mergers -- cost efficiency, profit efficiency, and market power in setting prices -- can be evaluated and compared using the same data set. In addition, we test several hypotheses regarding the ex ante conditions that may help predict which mergers are likely to increase efficiency or promote the exercise of market power.

By way of anticipation, the findings suggest that there are statistically significant increases in profit efficiency associated with U.S. bank megamergers on average, although there do not appear to be significant cost efficiency improvements on average. The improvement in average profit efficiency in part reflects a product mix shift from securities to loans, increasing the value of output. The data are consistent with the hypothesis that megamergers tend to diversify the portfolio and reduce risk, which allows the consolidated bank to issue more loans for about the same amount of equity capital, raising profits on average. The profit efficiency improvements can be fairly well predicted -- they tend to occur when either or both of the merging firms are inefficient relative to the industry prior to the merger.

The changes in market power associated with megamergers -- as reflected in changes in prices subsequent to the mergers -- are found to be very small on average and not statistically significant, although they are predictable to some degree. These results are consistent with the hypothesis that antitrust policy has been fairly successful in preventing mergers that would bring about large increases in market power. However, it is not known whether this policy may have also prevented some mergers that might have increased efficiency substantially.

Section Il summarizes prior empirical studies of merger efficiency and market power, showing 
how our approach differs from past efforts. Section III presents the frontier profit function model used to measure profit efficiency and describes the data set. Section IV gives the estimated profit efficiency effects of mergers and a regression analysis of some ex ante factors that may predict these efficiency effects. Section V gives a similar analysis of the changes in market power as reflected in the price changes associated with the mergers. Section VI concludes.

\section{The Merger Literature Versus Our Approach}

Mergers and Cost Efficiency. Mergers can potentially improve cost efficiency by increasing scale efficiency, scope (product mix) efficiency, or X-efficiency (managerial efficiency). The findings in the banking literature suggest that scale and scope efficiency changes are unlikely to change unit costs by more than a few percent for large banks (which we study here). Any meaningful cost scale economies that are found typically apply only to relatively small banks. The potential is greater for cost X-efficiency gains by moving closer to the 'best-practice' cost frontier where cost is minimized for a given output bundle. The X-efficiency empirical findings suggest that on average, banks have costs that are about $20 \%$ to $25 \%$ above those of the observed best-practice banks. This result suggests that cost efficiency could be considerably improved by a merger in which a relatively efficient bank acquires a relatively inefficient bank and spreads its superior management talent over more resources. ${ }^{3}$

The empirical bank merger literature confirms this potential tor cost efficiency improvement from mergers. $^{4}$ However, this literature also suggests that the potential for cost efficiency improvement generally was not realized. Most merger studies compared simple cost ratios, such as the operating cost

\footnotetext{
${ }^{3}$ See the survey by Berger, Hunter, and Timme (1993) for summaries of the cost scale, scope, and X-efficiency literatures.

${ }^{4}$ Savage (1991) and Shaffer (1993) showed by simulation methods that the potential for scale efficiency gains from mergers between large banks is negligible, but that large X-efficiency gains are possible. Similarly, using actual merger data, Berger and Humphrey (1992) found that acquiring banks were substantially more cost X-efficient than the banks they acquired on average. This result confirms the potential for cost X-efficiency gains if the managers of the acquiring bank are able to run the consolidated bank after the merger as efficiently as they ran the acquiring bank before the merger.
} 
to total assets ratio, and typically found no substantial change in cost performance associated with bank mergers (e.g., Rhoades 1986,1990, Srinivasin 1992, Srinivasin and Wall 1992, Linder and Crane 1992, Pilloff 1996). There are methodological problems with using simple cost ratios to measure cost efficiency, including the fact that such ratios do not control for differences in input prices and output mix. ${ }^{5}$ Nevertheless, the results of these ratio studies are consistent with the small number of studies that calculated the efficiency effects of mergers by measuring the distance from the best-practice cost frontier and found little or no improvement on average in cost efficiency (Berger and Humphrey 1992, Rhoades 1993, Peristiani 1995, DeYoung 1996). For example, Berger and Humphrey (1992) found about a 5 percentage point average improvement in cost X-efficiency rank relative to peer group, but the improvement was not statistically significant. ${ }^{6}$

These academic findings seem to conflict with consultant studies which forecast considerable cost savings from large bank mergers -- as much as $30 \%$ of the operating expenses of the acquired bank. However, as discussed in detail in Berger and Humphrey (1992), the academic and consultant results do not necessarily disagree substantively. Rather, the academics and consultants tend to state their findings differently or use different denominators that may make their results appear inconsistent when they are actually fairly consistent with each other. ${ }^{?}$

All of the cost efficiency analyses share the problem that outputs are taken as given and the revenue effects of mergers are not considered. As noted above, the total output of the consolidated firm typically changes after a merger and there is no way to determine from cost analysis alone whether the

${ }^{5}$ See Berger and Humphrey (1992) for more discussion of these problems.

${ }^{6}$ See Rhoades (1994) for a survey of the cost and performance merger studies from 1980 to 1993.

${ }^{7}$ For example, since the average acquired bank represents about $30 \%$ of the consolidated bank, and since operating costs currently are about $45 \%$ of total expenses, a savings of $30 \%$ of the acquired bank's operating costs as claimed by consultants translates into only about $4 \%$ of the total consolidated expenses $[(30 \% \bullet 45 \%) \bullet .30]$, close to the results of academic studies. 
cost changes are greater than or less than the revenue changes. Thus, a determination that cost efficiency improved or worsened does not by itself necessarily imply that the firm has become more or less efficient overall, or become more or less profitable. As will be shown, profit efficiency solves this problem.

Mergers and Revenue and Profit Efficiency. Mergers might also improve revenue or profit efficiency by improving revenue or profit scale, scope, or X-efficiency, but the literature here is much more limited and therefore less definitive than for cost efficiency. Revenue X-inefficiency is the failure to produce the highest value of output for a given set of input quantities and output prices. A firm may be revenue $\mathrm{X}$-inefficient because it produces too few outputs for the given inputs, or is inside its production-possibilities frontier (analogous to the cost X-inefficiency of a firm that uses too many inputs to produce the given outputs). Alternatively, a firm may be revenue X-inefficient if it responds poorly to relative prices and produces too little of a high-priced output and too much of a low-priced output, even if it is on the production-possibilities frontier (analogous to the cost inefficiency of a technically efficient firm that employs too much of a relatively high priced input). Thus, revenue $\mathrm{X}$-inefficiencies are fully analogous to cost $\mathrm{X}$-inefficiencies, as both involve a net loss of value added, but just differ as to whether the loss is in terms of a lower value of output produced or a higher value of inputs consumed. ${ }^{8}$ If the assumption of exogenously determined prices is dropped and allowance is made for market power in price setting, revenue scale and scope economies can also occur. ${ }^{9}$ Thus, revenue

${ }^{8}$ Revenue X-inefficiency is not usually directly measured, but can be inferred from analysis of an output distance function, which is an alternative way to measure output inefficiencies. An output distance function applied to banking data suggested that revenue or output inefficiencies were on the same order of magnitude or perhaps somewhat greater than the typical cost inefficiencies findings in other research (English, Grosskopf, Hayes, and Yaisawarng 1993).

${ }^{9}$ Revenues can more than double if output doubles (scale economies), or revenue may increase by producing two products jointly rather than separately (scope economies) if large firms or joint-production firms can charge higher prices for their services. This may occur if customers prefer services that can only be provided by a larger firm, or if customers enjoy the additional convenience of 'one-stop shopping,' having a greater variety of services delivered by the same firm. These customer preferences may be reflected in higher revenues for the firms that provide the extra services, provided that these firms have the market power to extract some of this consumer surplus. The one study of this topic in banking 
efficiencies appear to offer the same type of opportunity for improvement from mergers as cost efficiency, but there has been no investigation of whether this potential has been realized in actual mergers.

Profit efficiencies incorporate both cost and revenue efficiencies and their interactions, but have received little academic attention. Profit efficiency studies of U.S. banks found that estimated inefficiencies were usually quite large, about one-third to two-thirds of potential profits may be lost due to inefficiency. In addition, it was found that most inefficiencies were due to deficient output revenues rather than excessive input costs. The estimated inefficiencies were primarily technical, so that banks were generally well inside their production-possibilities frontiers. Allocative inefficiencies, or errors in responding to market prices for inputs and outputs, were usually relatively small. ${ }^{10}$

There have been no profit efficiency studies of mergers in any industry to our knowledge. We argue that analysis of profit efficiency is more appropriate to the evaluation of mergers than cost efficiency. Profit efficiency takes into account both the cost and revenue effects of the changes in output scale and scope that typically occur subsequent to a merger. Cost efficiency analysis, which takes outputs as given, cannot evaluate whether any revenue changes from shifts in output offset the cost changes except in the special case in which outputs remain constant (i.e., the output vector of the consolidated firm equals sum of the output vectors of the acquirer and acquired firms prior to the merger). In

found revenue scale economies to be $4 \%$ or less of revenues, and revenue scope economies to be small and statistically insignificant (Berger, Humphrey, and Pulley 1995).

${ }^{10}$ These findings primarily reflect the results of Berger, Hancock, and Humphrey (1993) and DeYoung and Nolle (1995). Akhavein, Swamy, and Taubman (1994) also obtained qualitatively similar results when their analysis was restricted to those observations in which the predicted netputs were of the correct sign (i.e., positive outputs and inputs). When this restriction was dropped, their measured profit inefficiencies became very small. Berger, Cummins, and Weiss (1995) found profit inefficiencies of similar magnitudes in the insurance industry. Humphrey and Pulley (1995) found somewhat smaller profit inefficiencies for banks, but they were examining interquartile differences in efficiency, rather than average inefficiencies. Berger, Cummins, and Weiss (1995) and Humphrey and Pulley (1995) used both the standard profit function (which takes output prices as given) and a nonstandard profit function (which takes output quantities as given). 
addition, profit efficiency is the more general concept that includes cost efficiency, so evaluation of profit efficiency changes associated with mergers incorporates whatever changes in cost efficiency occur plus the revenue and cost effects of changes in output. For policy analysis, it is appropriate to consider both the change in the value of real resources consumed, which is represented by the change in costs, and the change in the real value of output produced, which is represented by the change in revenues for given prices, and this is accomplished through evaluating profit efficiency. ${ }^{11}$

Although there are no profit efficiency studies of mergers, some studies have compared simple pre- and post-merger profitability ratios, such as the return on assets (ROA) or return on equity (ROE) based on accounting values. There is no consensus as to whether mergers increase profitability -- some of these studies found improved profitability ratios associated with bank mergers (e.g., Cornett and Tehranian 1992, Spindt and Tarhan 1992), although most others found no improvement in these ratios (e.g., Berger and Humphrey 1992, Linder and Crane 1992, Pilloff 1996)..$^{12,13}$

These profitability ratio studies have similar methodological problems to the cost ratios discussed above -- they do not control for input prices, and they simply divide by a crude indicator of bank scale (assets or equity). However, the more important problem is that without controls for output prices, there is no way to determine the source of any profitability change. The ROA and ROE ratios might increase

\footnotetext{
${ }^{11}$ Other advantages of profit efficiency over cost efficiency are discussed in Berger, Hancock, and Humphrey (1993).

${ }^{12}$ See Berger and Humphrey (1992) and Rhoades (1994) for extensive discussions of these ratio analyses. More recently, Schrantz (1993) also found higher profitability ratios for banks in states with relatively liberal takeover policies that make mergers and acquisitions relatively easy. However, it cannot be determined from such an analysis whether the profitability is derived from actual mergers and acquisitions or simply the greater perceived threat of them.

${ }^{13}$ In a related analysis, Fixler and Zieschang (1993) measured relative efficiency by the ratio of a value-weighted output index to a value-weighted input index. They found that acquiring banks were much more efficient than other banks prior to merger and maintained this advantage after merger. Given that other studies typically find acquiring banks to be more efficient than the banks they acquire, this suggests an improvement in total efficiency from mergers. Since they include an output index as well as an input index, the improvement could be from either revenue or cost sources.
} 
because of an improvement in profit efficiency associated with mergers -- in which quantities of outputs and inputs were altered for a given vector of input and output prices. Alternatively, an increase in market power associated with mergers -- in which the prices of bank products are made less favorable to consumers -- might be responsible for a finding of higher ROA or ROE after mergers. These two sources of profitability changes cannot be disentangled without a profit efficiency analysis. Similarly, merger event studies, which use market equity values rather than accounting data, cannot differentiate between efficiency and market power effects of mergers, since markets value profitability increases from all sources equally. ${ }^{14}$

Bank Mergers and Market Power. Under certain conditions, bank mergers also have the potential to raise profits through an increased exercise of market power in setting prices. Mergers between banks that have significant local market overlap ex ante may increase local market concentration and market share and allow the consolidated banks to raise profits by setting prices less favorable to consumers (higher loan rates, lower deposit rates). Mergers between banks in different regions generally do not affect local market structure significantly and are less likely to raise market power. If anything, such mergers may bring new aggressive competition to bear on previously imperfectly competitive markets and reduce the effects of market power. ${ }^{15}$ Note that increases in local market concentration and market share need not affect prices substantially if the local market is highly contestable, if there are

${ }^{14}$ Event studies usually find no improvement in the total market value of the consolidating banks associated with merger announcements. The market usually bids down the equity value of acquiring banks and bids up the value of the acquired banks, so the change in the combined equity value is usually not significantly different from zero (Hannan and Wolken 1989, Houston and Ryngaert 1994, Pilloff 1996). See Rhoades (1994) for a more complete summary of event study findings for bank mergers. In addition, the post-merger performance improvement has been found to be insignificantly related to the equity market's response to merger announcements (Pilloff 1996).

${ }^{15}$ Some banking products do trade in national markets, such as large corporate loans and large certificates of deposit. However, any increase in U.S. national concentration from individual bank mergers is unlikely to create significant market power at present because the national market is currently so unconcentrated. This may or may not remain the case in the future. 
significant nonbank alternative sources of similar services, or if there is a substantial coincident improvement in bank efficiency from the merger that is partially passed on in consumer prices.

Despite the antitrust policy focus on price effects of mergers, few academic studies exist which compare prices before and after mergers. An exception is Hannan and Prager(1995), which finds that mergers that violate the Justice Department guidelines for banks (local market Herfindahl over 1800, increase of over 200) sometimes substantially lower the deposit rates paid by banks in the affected markets, consistent with market power effects of mergers. They did not control for the efficiency effects of mergers, so that their results may incorporate some price effects of any change in efficiency as well. That is, if mergers increase operating efficiency and part of the change in efficiency is passed on in prices, the measured effect of mergers on prices may understate the market power effects. The measured market power effects may be overstated if mergers reduce efficiency. ${ }^{16}$

Some further insights into this problem may be gained by examining the larger literature regarding the effects of market concentration and market share on prices and profits. It should be borne in mind that there may be many differences between the dynamic effects of mergers on performance and the static equilibrium relationships between market structure and performance.

There are two opposing sets of theories regarding the relationships between market structure (concentration and market share) and both prices and profits. According to traditional market power hypotheses (including the structure-conduct-performance hypothesis), high concentration and/or market share are associated with prices that are less favorable to consumers which in turn create higher profits for producers. In contrast, according to the efficient-structure hypothesis (Demsetz 1973, Peltzman 1977), concentration and market share are positively related to firm efficiency, with more efficient firms

\footnotetext{
${ }^{16}$ Price effects of mergers have also been studied outside of banking. Kim and Singal (1993) found that airlines raised prices substantially after mergers. They acknowledged, however, that because they did not control for efficiency changes, their price changes incorporated confounding effects of market power and efficiency changes which could not be separately identified.
} 
growing larger and gaining dominant market shares. Under the efficient-structure hypothesis, high concentration and market share may be associated with prices that are more favorable to consumers if some of the efficiency savings are passed on to consumers (possibly as part of the process of gaining dominant market shares). The greater average efficiency of firms in more concentrated markets and with higher market shares will also yield higher profits for these firms. The empirical literature on the determination of prices and profits provides some support for both sets of theories. ${ }^{17}$

This brief summary of theory has two main implications for empirical studies of the effects of market power. First, the analysis should focus primarily on prices, rather than profits, since the marketpower theories have opposite predictions from the efficient-structure theory regarding relationship between market structure and prices but sometimes yield the same prediction for the market structure-profit association. Second, any analysis of either prices or profits should control for efficiency. Otherwise, the observed relationship between market structure and prices or profits may confound the effects of

\footnotetext{
${ }^{17}$ Studies of the effects of market power on bank prices have generally found that banks that operate in more concentrated local markets pay lower rates on deposits (e.g., Berger and Hannan 1989) and charge higher rates on loans (e.g., Hannan 1991), consistent with the market power hypotheses. However, these studies generally failed to control for efficiency in their analyses, creating a possible bias in the measured effect of market power, since efficiency may be correlated with the regressors (concentration, market share) and efficiency may bean important determinant of the dependent variable (price). Berger and Hannan (1996) addressed this problem by including direct measures of efficiency in the analysis and still found strong evidence of market power in setting loan and deposit prices.

Other studies of the association between profitability and market structure in banking and elsewhere often found that market share (but not concentration) was positively related to profitability when both market share and concentration were included in the profitability regression. However, there is disagreement over whether market share represents the exercise of market power on differentiated products (e.g., Rhoades 1985, Shepherd 1986) or firm efficiency which was left out of the model (e.g., Smirlock, Gilligan, and Marshall 1984, Smirlock 1985). Recent analyses (Berger 1995a, Berger and Hannar 1996) tried to resolve this problem by adding direct measures of efficiency to the analysis. They generally found that concentration and market share had little effect on profitability after controlling for efficiency, despite the market power effects on prices.

Thus, substantial market power from high levels of concentration or market share appear to have substantial effects on prices, but not on profitability. One possible explanation of this discrepancy may be a 'quiet-life' effect in which firms take part of any benefit of market power in the form of less rigorous adherence to efficiency maximization. In this event, part of the gains from pricing may be reflected in lower efficiency rather than in higher profits. Berger and Hannan $(1995,1996)$ found evidence consistent with quiet-life effects in banking.
} 
market power and efficiency, without allowing separate identification of either effect.

In sum, the literature suggests that bank mergers have the potential to increase profitability through increases in cost efficiency, profit efficiency, or market power in setting prices. Studies of cost ratios and cost efficiency generally found that the potential for cost efficiency improvement was not realized for most mergers. In contrast, there have been no academic studies of the profit efficiency effects of mergers and very little research on the market power effects of bank mergers. Studies of the effects of mergers on profitability ratios or equity values may confound changes in profit efficiency with changes in the exercise of market power in setting prices. Studies of the effects of equilibrium market structure on prices and profits provide some support for both market power and efficient structure effects of concentration and market share. In the remainder of this paper, we investigate both the profit efficiency and market power effects of mergers and try to identify ex ante conditions that predict when either profit efficiency or market power is likely to be increased.

\section{The Measurement of Profit Efficiency}

Determining Profit Efficiency. For the purpose of evaluating whether and by how much bank megamergers affect profit efficiency, we estimate the profit efficiency of all large U.S. banks (assets over \$1 billion) over the period 1980-1990, whether or not they were involved in megamergers. For each megamerger, we calculate the improvement in efficiency associated with the merger as the efficiency rank of the consolidated bank after the merger less the weighted average rank of the acquiring and acquired banks before the merger. In all cases, the efficiency rank is calculated relative to the peer group of all large banks that had data available over exactly the same time period as the consolidated or merging bank. In this way, we control for any industry-wide changes in profits or efficiency that may occur and keep the data consistent and comparable over time.

The specification of the profit function and estimation of profit efficiency closely follow the procedures of Berger, Hancock, and Humphrey (1993). We estimate a modified Fuss normalized 
quadratic variable profit function as well as quantity equations which embody cross-equation restrictions that help identify the model (similar to the more commonly specified input cost share equations). Thus, the profit model is given by:

(1)

$$
\begin{aligned}
& \frac{\pi(p, z, \tau, \xi)}{p_{n}}=\sum_{i=1}^{n-1}\left(\alpha_{i}-\xi_{i}\right) \frac{p_{i}}{p_{n}}+\sum_{i=1}^{n-1} \sum_{j=1}^{n-1} \phi_{i j}\left(1-1 / 2 \tau_{i}\right) \tau_{j} \frac{p_{i} p_{j}}{p_{n}^{2}} \\
& +\sum_{r=1}^{k} \beta_{r} z_{r}+\frac{1}{2} \sum_{r=1}^{k} \sum_{s=1}^{k} \theta_{r s} z_{r} z_{s}+\sum_{i=1}^{n-1} \sum_{r=1}^{k} \gamma_{i r} \frac{p_{i}}{p_{n}} z_{r}+\varepsilon_{n}-\xi_{n} \\
& \text { (2) } q_{i}=\alpha_{i}+\sum_{j=1}^{n-1} \phi_{i j} \tau_{j} \frac{n_{j}}{p_{n}}+\sum_{r=1}^{k} \gamma_{i r} z_{r}+6,-6,, \quad i=1, \ldots, n-1
\end{aligned}
$$

where $\pi$ is variable profits $\mathrm{p} \bullet \mathrm{q} ; \mathrm{p}$ is the price vector for $\mathrm{n}$ variable netputs (outputs and inputs); $\mathrm{q}$ is the vector of netput quantities supplied (with inputs measured as negative netputs); $\mathbf{z}$ is a vector of $\mathbf{k}$ fixed netputs; $\alpha, \phi, \beta, \theta$, and $\gamma$ are conventional regression coefficients with symmetry imposed $\left(\phi_{\mathrm{ij}}=\phi_{\mathrm{ji}}, \theta_{\mathrm{rs}}\right.$ $=\theta_{\mathrm{ar}}$ ), the $\epsilon$ 's are random errors; and the $\tau$ and $\xi$ vectors are used to measure allocative and technical inefficiencies, respectively. This functional form in (1) is better suited to the profit function than the often specified translog form, since it easily allows for zero or negative values for profits and fixed netputs. Linear homogeneity in the netput prices is imposed by normalizing the variable profits and prices by the price of the last netput. ${ }^{18}$

\footnotetext{
${ }^{18} \mathrm{~A}$ concern with this specification is that it takes prices as given, an assumption that may be violated if the firm exercises market power in setting prices. However, our results below suggest that no serious bias has been created by this assumption. First, in separate regression of the price effects of mergers, we find that estimated market power effects of mergers are extremely small relative to profits. These effects are also very small relative to the estimated effects of mergers on profit efficiency through changes in netput quantities. Second, the allocative inefficiencies, which depends on price effects, are found to be negligible in the results below, suggesting that prices are fairly unimportant in determining profits.
} 
Allocative inefficiency is defined as the loss of profits from making non-profit-maximizing choices of netputs in the production plan. Allocative inefficiency is modeled as if the bank were responding to shadow relative prices rather than actual relative prices -- maximizing profits as if $\tau_{\mathrm{i}} \bullet \mathrm{p}_{\mathrm{i}} / \mathrm{p}_{\mathrm{n}}$ were the relative price of netput $i$ to netput $n$ rather than $p_{i} / p_{n}$. Allocative inefficiency is measured as the loss of profits from $\tau$ being different from a vector of 1 's, or $\pi(\mathrm{p}, \mathrm{z}, 1, \xi)-\pi(\mathrm{p}, \mathrm{z}, \tau, \xi)=\Sigma_{\mathrm{i}=1, \ldots, \mathrm{n}-1} \Sigma_{\mathrm{j}=1, \ldots, \mathrm{n}-1} \phi_{\mathrm{ij}}$ $\left[1 / 2-\left(1-1 / 2 \tau_{\mathrm{i}}\right) \tau_{\mathrm{j}}\right] \mathrm{p}_{\mathrm{i}} \mathrm{p}_{\mathrm{j}} / \mathrm{p}_{\mathrm{p}}$.

Technical inefficiency is defined as the loss of profits from failing to meet the production plan. Technical inefficiency is modeled as each of the netputsi being $\xi_{i}$ below the efficient frontier, i.e., the outputs being too low or the inputs being too high. Technical inefficiency is measured as the loss of profits from $\xi$ being different from a vector of 0 's, or $\pi(\mathrm{p}, \mathbf{z}, \tau, 0)-\pi(\mathrm{p}, \mathbf{z}, \tau, \xi)=\Sigma_{\mathrm{i}=1, \ldots, \mathrm{n}} \xi_{\mathrm{i}} \mathrm{p}_{\mathrm{i}}$.

A fully efficient firm with no allocative or technical inefficiencies would earn the maximum or optimal level of profits for its given variable netput prices $p$ and fixed netput quantities $z$, or $\pi^{\circ}=$ $\pi(p, z, 1,0)$. The total profit efficiency ratio for each bank is measured as the ratio of actual profits to optimal profits, $\pi / \pi^{\circ}=\pi(\mathrm{p}, \mathrm{z}, \tau, \xi) / \pi(\mathrm{p}, \mathrm{z}, 1,0)$. Both the numerator and the denominator in this formula are measured as predicted values that exclude the random error terms. The efficiency ratio varies over the range $(-\infty, 1]$-- the best a firm can do is earn all of optimal profits $\left(\pi / \pi^{\circ}=1\right)$, but the worst a firm can do is unbounded since the firm can always make arbitrarily large losses by using more inputs without producing more outputs. For the purposes of this study, we focus on the total efficiency ratio, which incorporates both allocative and technical efficiencies. ${ }^{19}$

Finally, we try specifying an alternative, nonstandard profit function below that removes output prices from the specification in favor of output quantities. The main results of the model are materially unchanged, strongly suggesting that any problems with the specification of prices in the profit function are not important.

${ }^{19} \mathrm{By}$ construction, allocative and technical inefficiencies add up to total inefficiency and do not interact, since the level of allocative inefficiency is unaffected by $\xi$ and the level of technical inefficiency is unaffected by $\tau$. 
Our specification of the profit model in (1) and (2) includes four variable netputs $(n=4)$. Total loans and total securities (securities measured as all assets other than loans) are the outputs, and total deposit funds (including purchased funds) and labor are the inputs. Equity capital is the sole fixed netput. The specification is parsimonious because of the difficulty of estimating a nonlinear system with crossequation restrictions. The choices of outputs and inputs is consistent with the intermediation or asset approach of Sealey and Lindley (1977), under which intermediated assets are the outputs and sources of funding are the inputs of a financial institution. ${ }^{20}$ The specification of equity as a fixed input addresses the potential problem that the size of a bank, especially its loan portfolio, is strongly tied by both regulators and markets to its quantity of equity capital available to absorb loan losses. Equity is very difficult and costly to change substantially except over the long run, and so we treat this important input as fixed. If equity were not specified as fixed, the largest banks may be measured as the most profit efficient simply because their higher capital levels allow them to have the most loans. ${ }^{21}$ Our specification as a whole may be thought of as measuring efficiency by how well the firm is able to earn a return on equity by using deposit funds and labor to produce loans and securities.

The model in equations (1) and (2) is estimated by nonlinear iterative Seemingly Unrelated Regression techniques (NITSUR). ${ }^{22}$ We use data for all U.S. banking organizations -- both merging

${ }^{20}$ Deposits have both input and output attributes, and have been modeled as such in cost functions by specifying both deposit quantities and prices (e.g., Berger and Humphrey 1991). However, deposits cannot be modeled as having both traits in the variable profit function, which does not allow for quantities of variable outputs.

${ }^{21}$ Equity capital is preferred to the value of fixed assets (premises and equipment) as a fixed input. Fixed assets are very small in banking, only about $20 \%$ as large as equity, and can be increased much more quickly and easily than equity.

${ }^{2}$ Profit function convexity in prices is imposed by constraining the matrix of $\phi_{\mathrm{ij}}$ to be positive semidefinite, which assures nonnegative allocative inefficiency. The model is first estimated unconstrained and the positive semidefinite matrix that is 'closest' to the estimated $\Phi$ matrix (in the sense of minimizing the Euclidean norm of the difference) is selected. The other model parameters are then re-estimated given this revised $\Phi$ matrix. See Akhavein, Swamy, and Taubman (1994). 
and nonmerging -- annually from 1980 to 1990 that had assets of at least $\$ 1$ billion in at least one year over that interval. However, the organization need not be present in all years to be in the data set. Besides eliminating the small banking organizations, the only deletion is that data from the merger year itself are left out for the consolidated banks involved in megamergers. This is because such data are likely to contain very significant one-time transition costs. Efficiency is calculated for each of the at least three entities involved in a merger:1) the acquiring bank during the available years before the merger, 2) the acquired bank or banks during the available years before the merger, and 3) the consolidated bank during the available years after the merger. All of the efficiency levels and ranks of the merging banks are determined relative to peer groups of large banks that have data available over exactly the same time intervals. As described below, this generally involves tracking separate peer groups of large banks for each merger.

The allocative inefficiencies for each bank (the losses from a poor production plan) are estimated from the $\tau_{\mathrm{i}}$, the conventional profit function parameters, and the prices for that bank. To keep the model manageable, the $\tau_{\mathrm{i}}, \mathrm{i}=1,2,3$ are treated as parameters that are constant across banks. Unfortunately, this limits the variability of allocative inefficiency across firms, but most prior research suggests that this may not be important because allocative inefficiencies are usually found to be small relative to technical inefficiencies (e.g., Aly, Grabowski, Pasurka, and Rangan 1990, Berger and Humphrey 1991, Berger, Hancock, and Humphrey 1993). ${ }^{23}$

To estimate the technical inefficiencies (the losses from failing to meet the production plan), we follow the 'distribution-free' approach of Berger (1993), which is based on Sickles and Schmidt (1984). Each of the 4 equations in (1) and (2) contains a composed error term $\left(\epsilon_{\mathrm{i}}-\xi_{\mathrm{i}}\right)$, a random error term minus the technical inefficiency in netput i for the individual firm. The distribution-free approach separates the

\footnotetext{
${ }^{23}$ Exceptions that sometimes find allocative inefficiencies to be relatively large are Ferrier and Lovell (1990) and Akhavein, Swamy, and Taubman (1994).
} 
technical inefficiency from the random error by assuming that inefficiency is constant over the time interval of measurement, whereas the random error tends to average out over time. Thus, the $\xi_{\mathrm{i}}, \mathrm{i}=$ $1, \ldots, 4$ for each bank involved in a merger is estimated by the difference between the maximum average residual from the equation containing $\epsilon_{\mathrm{i}}-\xi_{\mathrm{i}}$ for the sample of banks with complete data over the corresponding time interval and the average residual for the bank in question. If the efficiencies are not perfectly constant over the time interval, the measured technical inefficiencies may be interpreted as the deviations of the average practice of the bank from the best average practice frontier. When computing the level of efficiency (not the rank), we also truncate the average residuals of each bank by assigning the most extreme $5 \%$ at the top and bottom of the distribution to the 95 th and 5 th percentage points, respectively, to further reduce the effects of random error.

The Megamerger Data Set. We collected data on all mergers of U.S. banking organizations during 1981-1989 in which both partners had at least $\$ 1$ billion in assets. All but a few of these mergers were between holding companies rather than between individual banks. For our analysis, we treat the 'high' holding company -- the holding company which is not owned by any other holding company -- as the decision making unit that tries to maximize profits. That is, we sum together all the commercial banks that are jointly owned through the holding company structure and treat them as a single profitmaximizing unit (although for convenience we sometimes still refer to the consolidated entity as a bank). This is consistent with the efficiency claims made by bank consultants, which imply that the mergerrelated efficiency improvements are made in a coordinated way through the holding company structure. Bank regulators and the Justice Department similarly focus on market structure (concentration, market share) at the holding company level.

The expected time pattern of costs and revenues associated with bank mergers is that some extra nonrecurring or transitional costs (e.g., legal expenses, consultant fees, severance pay, etc.) will occur in the short term, but that other recurring expenses will fall and longer-term revenues may rise. Thus, 
it is expected that profits may be temporarily lower during this transition but possibly higher afterwards. Ideally, to judge the benefit of a merger, one would determine the present value of all future profit improvements after a merger. Since this is not possible, we simply drop the data from the year of the merger to reduce the effects of transition costs. Fortunately, Berger and Humphrey (1992) found that merger cost results remained materially unchanged whether the single year of data, 2 years of data, or 3 years of data subsequent to the mergers were dropped, suggesting that our treatment of transition costs likely does not create serious biases.

The netput quantities and prices were constructed from Call Report information over 1980-1990. The ex post efficiency and performance indicators for the consolidated bank after the merger were based on all the years following the merger until either another megamerger involving that bank occurred or the year 1990 was reached. The pre-merger efficiency of the acquiring bank and the acquired bank(s) were based on all the years going backward in time prior to the merger until either another megamerger involving that bank or the year 1980 was reached. In the usual case in which exactly two banking organizations merged, this involves computing the efficiency measures for 3 banks, each over a different time interval -- the appropriate years after the merger for the consolidated entity and the appropriate years prior to the merger for both the acquiring and the acquired bank separately. ${ }^{24}$ If a bank acquired more than one other bank in the same or consecutive years, these were combined into a single merger observation with additional pre-merger intervals over which efficiency is measured. In all cases, the data on merging banks were compared to the set of large banks with complete data over the same time interval. If data were unavailable for the merging banks for any of the intervals, the merger was not used in the efficiency analysis. In many cases, the data were unavailable because one of the entities was a

\footnotetext{
${ }^{24}$ For example, suppose bank A (in existence since before 1980) acquired bank B in 1988, and bank B had acquired bank $C$ in 1984. For the 1988 A-B merger, the ex post data on the consolidated bank would be on A's performance over 1989-90, the ex ante data on the acquiring bank would be on A's performance over 1980-87, and the ex ante data on the acquired bank would be on B over 1985-87.
} 
thrift or a foreign-owned institution without comparable data available. In all, 69 of the 114 megamergers over 1981-1989 were retained, although they appear in only 57 observations since some observations contain mergers among 2,3, or 4 entities. See Berger and Humphrey (1992) for additional details about the data set.

IV. The Profit Efficiency Effects of Megamergers

The Level of Profit Efficiency. We begin discussing the results with some information on the levels of profit efficiency of merging and nonmerging banks. The more rigorous comparisons of the efficiency ranks will be discussed below.ablel ppemestion standard profit efficiency model in equations (1) and (2) above, and Table A2 gives the estimated parameters of the model.

The level of profit efficiency -- the ratio of predicted profits to maximum or optimal profits on the frontier $\left(\pi / \pi^{\circ}\right)$-- was measured for all large banks over 1980-1990, whether or not they were involved in megamergers. For each firm's prices $\mathrm{p}$ and fixed netputs $\mathrm{z}$, we take the ratio of the predicted values of profits using the estimated values of $\tau$ and $\xi, \pi(p, z, \tau, \xi)$, divided by the predicted value with vectors of 1's and O's replacing $\tau$ and $\xi$, respectively, or $\pi(\mathrm{p}, \mathrm{z}, 1,0)$.

Merging banks improved their profit efficiency substantially after mergers. The asset-weighted average of the acquiring and acquired banks prior to megamergers was $44 \%$, and rose to $71 \%$ for the consolidated banks after merging, a statistically significant increase of 27 percentage points. That is, the asset-weighted average of banks that participated in mergers earned $44 \%$ of optimal profits before the mergers, and the consolidated banks earned $71 \%$ of maximum profits after the mergers. However, this does not necessarily indicate a merger-related improvement in efficiency because profit efficiencies may vary with the number of observations available and the economic environment of the banks, which can change fairly rapidly with variations in open-market interest rates (which fell substantially over the 1980s). 
What matters instead is how the measured improvement for a merging bank compares with the measured improvement for its peer group of large banks with data over the same pre- and post-merger periods as the merging bank. Putting together the peer groups for all 57 megamergers, the weighted average pre-merger profit efficiency level for all banks was $24 \%$ before the mergers, and rose to $34 \%$ after the mergers, for a statistically significant increase of 10 percentage points. That is, the assetweighted average of all large banks that had consistent data over the same time periods as the acquiring and acquired banks prior to the mergers earned $24 \%$ of optimal profits, while those in existence over the same time periods as the consolidated banks after the mergers earned $34 \%$ of maximum profits. This result suggests that profit efficiencies do vary with the economic environment of the banks, but not enough to explain the efficiency improvement of the merging banks. Subtracting the 10 percentage point improvement of all banks from the 27 percentage point increase for merging banks leaves a 17 percentage point additional increase in efficiency associated with megamergers. Thus, banks that chose to merge were more profit efficient on average than other banks ex ante, and appeared to add to this advantage by improving their efficiency by more than other banks ex post.

Profit efficiency for merging banks can be decomposed into technical and allocative components. The average level of technical efficiency was $46 \%$ before a merger and $73 \%$ afterwards, rising 27 percentage points and mirroring the situation for overall profit efficiency. Allocative efficiency was already high for these banks prior to merging, an average of $\mathbf{9 8 . 3 \%}$, and was little changed after merging, falling by $0.1 \%$ to $98.2 \%$. This confirms our speculation based on prior research that allocative inefficiency would be small relative to technical inefficiency, so that cross-sectional variations in allocative inefficiency (which are mostly suppressed by our assumption of constant $\tau$ 's) would likely not be important.

Profit efficiency can also be decomposed into output and input components. Output ineftiiciency in the profit function includes the output technical inefficiency (failure to produce as much output as 
planned) and allocative inefficiency from misresponding to output prices (including the cost and revenue effects of deviating from the profit-maximizing production plan). Input inefficiency is defined similarly. ${ }^{25}$ For merging banks, output efficiency climbed 13 percentage points (from $69 \%$ pre-merger to $82 \%$ post-merger), while input efficiency rose 14 percentage points (from $75 \%$ to $89 \%$ ). Thus, both input and output efficiency improved subsequent to mergers. Note that the rise in input efficiency does not necessarily imply any change in cost X-efficiency. This is because the change in input efficiency incorporates part of the change in outputs subsequent to the merger. For example, if planned outputs are smaller and require fewer inputs, inputs may be closer to their optimal levels and input efficiency may be improved, but cost X-efficiency is unchanged because it takes outputs as given. Only in the special case in which outputs remain constant does the change in input inefficiency necessarily reflect a change in cost $\mathrm{X}$-efficiency, and as shown below, the outputs do change after a merger.

In the remainder of the analysis, we focus simply on the total efficiency ranks of the merging banks, rather than dealing with the cumbersome array of components of efficiency or with the level of efficiency. The use of total efficiency, the ratio of predicted profits to optimal profits $\left(\pi / \pi^{\circ}\right)$, corresponds well to the social benefit concept of the real value of output produced less the real value of resources consumed. The rank of total efficiency is preferred to the level because the rank is neutral with respect to changes in the distribution of measured efficiency over time, which do seem to occur. In addition, our 'distribution-free' methodology -- in which the random error is averaged out over time -introduces some biases into the measurement of the levels of relative efficiency because different numbers of observations are available for different mergers. Fortunately, the expected value of the efficiency rank does not depend on the number of observations (although the variation in the measured rank around the true rank obviously does depend on the number of observations). As will be shown, our main results

\footnotetext{
${ }^{25}$ For the purposes of discussion here, we somewhat arbitrarily count the very small amount of inputoutput price allocative inefficiency -- the interaction of misresponding to input and output prices -- as output inefficiency (see Berger, Hancock, and Humphrey, 1993).
} 
are also robust to the use of rank or level.

Changes In Profit Efficiency Rank. We compute the rank of a merging bank (acquiring, acquired, or consolidated) relative to its peer group of large banks with contemporaneous data as the proportion of peer group with efficiency below that of the merging bank. Thus, a merging bank with total efficiency $\left(\pi / \pi^{\circ}\right)$ better than $80 \%$ of its peer group is assigned a rank of .80 .

Both the pre- and post-merger ranks, along with the resulting change in rank, are reported in Column 1 of Table 1. The pre-merger profit efficiency rank of merging banks, which is an assetweighted average of the acquiring and acquired bank's efficiency rank, averaged .74. Consistent with the efficiency levels discussed above, merging banks are more efficient on average than $74 \%$ of all large banks prior to merger. After the mergers, the average profit efficiency rank increased to $.90 .{ }^{26}$ Thus, the average bank megamerger is associated with a statistically significant 16 percentage point increase in rank. This is consistent with the merger-related 17 percentage point improvement in average profit efficiency level relative to the peer group change reported above.

While profit efficiency is our preferred measure to gauge the profit effects of bank megamergers, it is helpful to compare the results with standard profitability ratios, return on assets (ROA) and return on equity (ROE), which should incorporate some profit efficiency effects as well as any market power effects of mergers. We remove from the standard measures the confounding effects of variations in taxes paid and loan loss provisions, which often fluctuate substantially over time in ways that do not reflect operating efficiency. We refer to these measures with the noisy components of net income removed as adjusted returns on assets $\left(\mathrm{ROA}^{\mathrm{a}}\right)$ and equity $\left(\mathrm{ROE}^{\mathrm{a}}\right) .^{27}$

\footnotetext{
${ }^{26}$ Although this profit efficiency rank of .90 is seemingly high, it is not necessarily indicative of a high efficiency level. On average, consolidated banks had a profit efficiency level of $71 \%$-- i.e., they lost an estimated $29 \%$ of their potential profits to inefficiency.

${ }^{27}$ Thus, $\mathrm{ROA}^{\mathrm{a}}=\mathrm{NI}^{\mathrm{a}} / \mathrm{TA}$ and $\mathrm{ROE}^{\mathrm{a}}=\mathrm{NI}^{\mathrm{a}} / \mathrm{EQ}$, where $\mathrm{NI}^{\mathrm{a}}$ is net income plus taxes and provisions, $\mathrm{TA}=$ total assets and $\mathrm{EQ}=$ equity capital. The average $\mathrm{ROA}^{\mathrm{a}}\left(\mathrm{ROE}^{\mathrm{a}}\right)$ level for merging banks was $1.4 \%(22 \%)$ pre-merger and improved to $1.6 \%(23 \%)$ post-merger.
} 
As shown in Table 1, the ROA ${ }^{\mathrm{a}}$ rank of merging banks increased an average 5 percentage points (from a rank of .52 to .57 ) and the rank of $\mathrm{ROE}^{\mathrm{a}}$ improved by 3 percentage points (from .62 to .65). Neither of these changes are statistically significant. ${ }^{28}$ Thus, the measured improvements in profit efficiency are not well reflected in the ranks of the more commonly used profitability ratios ROA and ROE (adjusted or unadjusted). As noted earlier, the profitability ratios may be inaccurate indicators of performance because they do not take account of differences in the prices faced by the banking firms, and these ratios divide earnings by crude measures of bank size, total assets or equity capital, rather than by the potential profits $\pi^{\circ}$ benchmark, which is the highest profits that can be earned for the equity and prices faced by the firm. When adjusted net income was divided by potential profits $\left(\mathrm{NI}^{\mathrm{a}} / \pi^{\circ}\right)$, merging firms improved by a statistically significant 12 percentage points in average rank from .76 to .88 (not shown), much closer to the profit efficiency results. Perhaps more important from an analytical viewpoint, the changes in profitability ratios confound two major effects that should be separated when evaluating mergers -- changes in efficiency and changes in market power in price setting. Thus, it is perhaps not too surprising and perhaps partially explainable why the changes in the standard profitability ratios differ from the measured efficiency rank improvements.

Columns 2 and 3 of Table 1 show the same pre- and post-merger efficiency and profitability ranks and changes in rank for merging banks with in lowest and highest thirds, respectively, in terms of premerger profit efficiency $\left(\pi / \pi^{\circ}\right)$ rank (weighted average of acquirer and acquired). Banks in the lowest third in terms of pre-merger profit efficiency rank moved from a rank of .56 up to a rank of .83, yielding a significant 27 percentage point improvement. Banks with the highest pre-merger rank moved from a rank of .92 up to .95 , giving only a 3 percentage point improvement in rank, although it is statistically significant. Thus, the banks that improved the most were generally those with the lowest pre-merger

\footnotetext{
${ }^{28}$ When the ranks of unadjusted $\mathrm{ROA}$ and ROE values were used (not shown), the merger-related improvements were $-.006 \overline{\text { and }-.034}$, respectively, neither of which was statistically significant.
} 
profit efficiency rank, and vice versa for banks with the highest pre-merger efficiency. This is clearly related to the opportunity to improve -- banks in the highest third were already at the 92nd percentage point in the distribution for profit efficiency, and so could not have the mean efficiency improvement of 16 percentage points shown in the first column of the table. A similar result is shown for the profitability ratios. Banks with low pre-merger profit efficiency experienced statistically significant improvements in their $\mathrm{ROA}^{\mathrm{a}}$ and $\mathrm{ROE}^{\mathrm{a}}$ of 11 and 16 percentage points, respectively. Thus, when profit efficienc movements are pronounced, they do appear in the profitability ratios, suggesting that these ratios do incorporate efficiency movements, but are not as sensitive as the profit efficiency rank when the efficiency movements are relatively small.

How Profit Efficiency Improves. The question now arises as to how or why we find a profit efficiency improvement from megamergers, whereas no cost efficiency improvement was found from these same mergers using the same data set in Berger and Humphrey (1992). As discussed above, the only special case in which it is guaranteed that the cost and profit efficiency effects of mergers will be the same is if the consolidated firm produces exactly the same output vector as the acquirer and acquired firms produced combined prior to the merger.

To explore this issue, we examined the output behavior of firms engaged in megamergers versus the same peer groups used in the efficiency calculations. Although merging and nonmerging firms both grew in size substantially after the mergers owing to trends in banking in the 1980s, firms engaged in megamergers had a decided shift in product mix relative to the other firms. Prior to mergers, merging firms had an average of $56.4 \%$ of total assets in the loan output, below the $59.5 \%$ of all large banks. Subsequent to the mergers, merging firms raised their average loan/total asset ratio almost 7 percentage points to $63.3 \%$, passing the peer group average for all large banks, which increased only 3.4 percentage points to $62.9 \%$. One hypothesis is that consolidated firms may have increased their focus on loans because their larger size, greater geographic spread, and/or broader industrial coverage allowed better 
diversification of risk, allowing for a proportionately larger loan portfolio with about the same amount of total risk. That is, under the Diversification Hypothesis the market rewarded the merging firms for an improved diversification of loan risks by allowing them to hold a higher loan/asset ratio, all else equal. Consolidated banks may also have chosen to be more aggressive in obtaining market share in loan markets because of their more prominent stature. In any event, the movement into lending represents an increase in the value of output produced and an improvement in profit efficiency, all else equal, since loans have higher returns on average than securities. This increase in profit efficiency will not be captured in cost efficiency, which takes outputs as given. ${ }^{29}$

To examine the Diversification Hypothesis further, we looked at the behavior of the equity/asset ratio before and after the merger. If the hypothesis is correct, then the higher loan ratio should not require an increase in the equity/asset ratio to finance. That is, we need to rule out the possibility that the higher loan/asset ratio was made possible by a decrease in leverage risk, rather than an improvement in risk diversification. The data show that prior to merger, the combined acquiring and acquired banks had a mean equity/asset ratio of 53 basis points below the mean of the peer group before the merger. This difference widened by 6 basis points after the merger -- consolidated banks had an average equity/asset ratio of 59 basis points below the mean of the peer group of large banking organizations over comparable years. These data are consistent with the Diversification Hvpothesis -- merging firms were able to take on both a substantially higher loan/asset ratio and a slightly increased leverage risk after the merger, possibly owing to the reduction of risks from diversification. It is possible that the merging banks wanted to lower their equity/asset ratio by more than 6 basis points relative to the peer group mean, but were prevented from doing so by regulatory capital standards, since most large banking organizations were very close to or in violation of the regulatory standards during the 1980 s.

\footnotetext{
${ }^{29}$ An increase $\mathrm{i}_{\text {n }}$ profit efficiency from diversifying loan risks would be consistent with the finding elsewhere that U.S. banks that reduced their risks in the 1980s tended to have higher earnings, primarily through reduced rates paid on uninsured debt (Berger 1995b).
} 
Interestingly, the increase in the loan/asset ratio may have been a second choice for many of these firms to increase expected earnings after receiving the benefits of risk diversification through mergers -- they may have raised lending because the regulatory capital requirements blocked a reduction in funding costs by switching from equity to debt and raising leverage..$^{30}$

Benston, Hunter, and Wall (1995) tested another implication of the Diversification Hypothesis using data on the prices bid to acquire banks in the early to mid-1980s. Under this hypothesis, it would be expected that acquiring banks would bid more for other banks that tended to reduce the variance of their combined earnings stream. Under an alternative hypothesis that the purpose of mergers is to increase the value of the deposit insurance put option, banks would bid more for other banks that would increase total risk or put the bank in a position in which it might be considered to be 'too big to fail. The data supported the Diversification Hvpothesis -- acquiring banks bid more for other banks with lower earnings variation and higher equity/asset ratios, all else held equal.

Hughes, Lang, Mester, and Moon (1996) also presented information consistent with the Diversification Hypothesis. They found that as banking organizations increase in size (through merger or otherwise), their risk-expected return tradeoff improves, presumably because of better diversification of portfolio risks. The larger firms tend to respond to these incentives by increasing both risk and expected return, consistent with the increased profit efficiency observed here for large banking organizations that merge, and consistent with the Diversification Hypothesis.

Similar to our analysis above of ex ante efficiencies of merging banks, we also tried constructing the thirds of the data by the pre-merger loan/asset ratio. The results (not shown) were that merging banks with weighted average loan/asset ratios in the lowest third of the data had lower average profit efficiency

\footnotetext{
${ }^{30}$ In nonfinancial industries, firms typically increase their leverage after a merger, bringing the risk of bankruptcy back up close to the desirable level after diversifying the risks (see Kim and McConnell 1977, Asquith and Kim 1983). Similarly, prior to implementation of formal capital requirements in the early 1980s, acquired banks were often found to increase their leverage following mergers (see Benston, Hunter, and Wall 1995 for a summary of these studies).
} 
than merging banks in the highest third (.73 versus .82 ), and also had higher average improvements in profit efficiency $(.18$ versus .11). These findings again suggest that the loan/asset ratio reflects profit efficiency and that efficiency improvements subsequent to mergers are related to the potential or capacity t o improve.

Another potential explanation of the increase in measured profit efficiency from megamergers may be the specification of the profit function. The standard profit function takes prices and fixed netputs as given and assumes that firms will be able to choose freely the size of their variable outputs (loans and securities). We generally find larger firms to be more profit efficient, a result that is typically found elsewhere. A potential problem is that it may be difficult or time-consuming for firms to change the size of their asset portfolio because of the size of their markets and/or because of regulatory restrictions on their expansion. In this event, the efficiency of smaller firms may be understand because they were unable to achieve efficient scale quickly and the profit efficiency gains from megamergers might be overstated because the merging firms tended to have fewer barriers to overcome in achieving more efficient size. As noted above, the specification of equity as a fixed netput in the profit function partially addresses this potential problem by only requiring banks to achieve the most profit for their given capital positions.

We go a step further here and specify a 'nonstandard' profit function, which treats all of the outputs as fixed, so that smaller firms that cannot expand are not disadvantaged. That is, we replace the output prices in the standard profit function with output quantities, so that profits are a function of output quantities, fixed netput quantities, and input prices. ${ }^{31}$ This nonstandard specification should effectively

\footnotetext{
${ }^{31}$ See Berger, Humphrey, and Pulley (1995), Berger, Cummins, and Weiss (1995), Pulley a n d Humphrey (1995) for previous specifications of the nonstandard form of revenue and profit functions. Note that the nonstandard form is usually alternatively motivated by a desire to allow for market power in output pricing, i.e., an assumption that outputs are relatively fixed and prices are chosen by the firm.
} 
eliminate most of any scale bias or merger bias..$^{32}$ The coefficients of the nonstandard profit function are shown in Append $\mathbf{x}$ Table A3. Fortunately, our main results are materially unchanged from the standard specification. Under the nonstandard specification, merging banks rise from a weighted average efficiency rank of .77 pre-merger to .90 post-merger (not shown in tables), quite similar to the rise in rank from .74 to .90 found using the standard specification. Thus, it seems unlikely that any scale bias in our econometric specification is primarily responsible for our findings of a substantial improvement in profit efficiency from megamergers in banking.

Sources of Profit Efficiency Improvement. As noted above, it is important for the purposes of antitrust policy to know if there are any identifiable ex ante conditions that are good predictors of efficiency improvements or changes in the exercise of market power in setting prices. There is a substantial dispersion in the findings -- some mergers appear to result in large increases in efficiency, whereas others appear to result in efficiency losses, and being able to predict which is which may be helpful in the merger approval/denial process.

We put forth two major hypotheses about the prediction of merger efficiency gains and examine the effects of several possible ex ante conditions in a regression analysis in which the dependent variable is the profit efficiency rank improvement after the merger. The independent variables representing these ex ante conditions, shown in Table 2, will also be used below to help predict changes in bank profitability and prices.

Conventional wisdom in banking asserts that well-run banks seek out and acquire poorly-run banks. A preference for poor performers as acquisition targets would not be surprising. Poorly performing banks typically have a relatively low market to book value of equity, making them

\footnotetext{
${ }^{32}$ Note that the nonstandard specification specifies the same exogenous variables as a standard cost function -- output and fixed netput quantities and input prices. The fact that cost studies in banking using these variables typically finds very few scale economies or diseconomies strongly suggests that controlling for these variables removes any significant scale or merger bias.
} 
comparatively cheap to acquire on a per dollar of assets or deposits basis. This value of the acquired part of the consolidated bank can potentially be increased by applying the managerial policies and procedures of the more efficient acquiring bank to it. Because of regulatory restrictions on combinations of banking and commerce, other commercial banks and bank holding companies are virtually the only type of firm that can purchase a commercial bank. Therefore, the market for corporate control can usually only work to improve managerial efficiency through the process of relatively efficient banking organizations acquiring relatively inefficient banks and raising their efficiency. As noted in the introduction, the potential market for corporate control in banking will be greatly expanded in the future when nationwide banking is allowed, and banking organizations from virtually anywhere in the nation will be able to compete for control of almost any banking organization.

We call this effect of relatively efficient banks taking over and reforming the practices of relatively inefficient banks the Relative Efficiency Hypothesis. We measure it using the variable W2(EFF1-EFF2), the difference in efficiency between the acquiring bank (EFF1) and the acquired bank (EFF2), weighted by the proportion of their combined pre-merger total assets accounted for by the acquired bank (W2 $\equiv \mathrm{TA2} /(\mathrm{TA} 1+\mathrm{TA} 2))$. The greater the difference in efficiency between the acquiring bank and the acquired bank -- i.e., the greater is EFF1-EFF2 -- the greater is the scope for improving performance. The W2 weight on this term is needed because the overall efficiency improvement of the consolidated firm should be directly proportional to the relative size of the acquired bank, the part of the consolidated bank that is postulated to improve. Thus, under this hypothesis, if the consolidated firm's efficiency is raised all the way to the level of the acquirer, the improvement in the consolidated firm (the dependent variable) will equal W2(EFF1-EFF2). The regression coefficient of this variable in predicting merger efficiency improvements is expected to be positive under the Relative Efficiency Hypothesis, and may be interpreted as the proportion of this potential ex ante improvement that is achieved ex post.

As shown in Table 2, the average W2(EFF1-EFF2) is only .05. This relatively small average 
suggests that if the Relative Efficiency Hypothesis is true, it is likely to raise the average efficiency rank of the merging banks by 5 percentage points or less. Moreover, the range of this variable -- from -..16 (where the acquired bank was less efficient than the acquired bank) to +.17 (where the acquiring bank is more efficient) -- suggests that adoption of the managerial policies and procedures of the acquiring bank may have a wide array of consequences, including some outcomes in which mergers reduce efficiency.

An alternative theory is that profit efficiency is more likely improved when the acquired and the acquiring banks are both poor performers prior to their merger. Here the merger event itself may have the effect of "waking up" management and be used as an "excuse" to implement substantial restructuring (including job cuts and reassignments) and efficiency improvements to increase the profitability of both parts of the combined institution. In the absence of a merger, a significant restructuring may not be undertaken because of the difficult and disruptive nature of the change. The remaining employees may have serious morale problems unless there is a merger or other external event on which to blame the restructuring. We call this the Low Efficiency Hypothesis and it predicts that the ex post improvement in efficiency after the merger will be higher if either or both of merging firms have low efficiency ranks prior to the merger, leaving room for both parts of the consolidated bank to improve. To test this hypothesis, we specify as exogenous variables the weighted ranks of the efficiency of both the acquirer and acquired banks, W1(EFF1) and W2(EFF2), respectively. The coefficients of both of these variables are predicted to be negative under this hypothesis because low efficiency indicates more capacity for the "waking up" to improve performance. The W1 and W2 weights are needed because the contribution of each of the merging firms to the improvement of the consolidated firm should be proportional to that firm's share of the consolidated bank. It may be difficult to distinguish the Low Efficiency Hvpothesis from the Relative Efficiency Hypothesis because both depend on almost the same ex ante efficiency variables and neither hypothesis nests the other one.

In addition to the Relative Efficiency Hypothesis and the Low Efficiency Hypothesis, we 
control for/investigate a number of other possible ex ante explanations of merger efficiency gains. We include W2, the measure of the relative size of the acquired bank to control for potential differences between "mergers of equals" and acquisitions of smaller banks. Mergers of equals, in which W2 is relatively close to .5 , may increase the expected gains from mergers because there may be greater cost savings from the elimination of parallel management structures. For example, in the 1986 Wells FargoCrocker merger of near equals, large cost savings were achieved by eliminating most of the Crocker management structure. Alternatively, acquisition of a relative small bank also has potential advantages, such as an easier integration of computer and accounting systems and fewer internal struggles for control. Note that these arguments are in addition to and separate from the Relative Efficiency and $\underline{\text { Low }}$ Efficiency Hypotheses, which also specify W2.

It is often argued by bank consultants that the greater the overlap in the local deposit markets of merging banks, the greater should be the cost savings from the merger ${ }^{33}$ This cost-based argument reflects an expectation that there is likely to be greater scope for consolidating back-office payment processing operations as well as eliminating duplicate branch offices, tellers, and mid-level management when bank offices are geographically proximate. For this reason, we include the variable OVERLAP - the proportion of the deposits of the merging banks that are in the same Metropolitan Statistical Areas (MSAs) or non-MSA counties -- in the regressions. However, prior academic studies of cost ratios and cost efficiency usually did not find significant effects of OVERLAP (Berger and Humphrey 1992, Srinivasin 1992, Srinivasin and Wall 1992, Rhoades 1993, Pilloff 1996). The degree of overlap in the megamergers of the 1980s averaged $34 \%$, although $70 \%$ of the mergers have at least some deposits in the same market.

We also control for regional economic conditions by including the average annual growth rate

\footnotetext{
${ }^{33}$ For example, Toves (1992) suggested that cost savings as much as $35 \%$ of the operating cost of the acquired bank may be expected for in-market mergers, but savings of only $15 \%$ may be expected with an out-of-market merger.
} 
of state personal income (STINCOME) for the acquiring and acquired banks (weighted average). This accounts for both population growth and per capita income growth, two important elements determining bank deposit expansion and the demand for consumer and business loans. If regions with high ex ante growth continue to grow at a high rate after the merger, then banks that merge in these regions may have superior changes in performance. Alternatively, if regional growth is not highly serially correlated, then mergers in regions with high ex ante growth may have relatively poor measured merger results, as the ex post efficiency and profitability is measured under more "normal" conditions that tend to be inferior to those prevailing before the mergers.

We include two variables that describe the local market structure in which the mergers take place. The variable HERF is the weighted average of the Herfindahl indices of the merging firms across the local deposit markets in which they have offices, and the variable SHARE gives their weighted average market share. As indicated earlier, these variables are closely examined by regulators and the Justice Department in the merger approval process, and have been shown to be associated with the exercise of market power in setting prices. Also noted earlier, firms in highly concentrated markets tend to be less cost efficient than other banks, presumably because the pressures to optimize become weaker when firms can raise profits by exercising greater market power in setting prices.

Two final possible influences on merger success included in the analysis are the degree of retail business focus (RETAIL) and the size of the banks being merged (SCALE). The variable RETAIL is the proportion of total assets funded by demand, time, and savings deposits, and may be important in measuring the potential for cost savings through branch closings. The variable SCALE is measured as the weighted average rank of total assets of the merging banks relative to all large banks, and may reflect the potential for changes in scale efficiency through the merger process.

Model and Results. We regress the improvement in profit efficiency rank $\Delta\left(\pi / \pi^{\circ}\right)$ on the ex ante variables discussed above and shown in Table 2. In the first regression, we examine the Relative 
Efficiency Hypothesis,_, which postulates that mergers will be more successful the larger is the difference in efficiency between the acquirer and acquired. The regression takes the form:

\section{(3) $\Delta\left(\pi / \pi^{\circ}\right)=\delta_{0}+\delta_{1}$ W2(EFF1-EFF2) $+\delta_{2}$ W2 $+\delta_{3}$ OVERLAP $+\delta_{4}$ HERF $+\delta_{5}$ SHARE $+\delta_{6}$ STINCOME $+\delta_{7}$ RETAIL $+\delta_{8}$ SCALE $+\mu$}

The results are shown in the first column of Table 3. The improvement in profit efficiency associated with the merger was significantly larger the greater was the difference in the pre-merger efficiency positions of the merging banks W2(EFF1-EFF2), consistent with the Relative Efficiency Hypothesis. The point of . 30 is statistically significantly different from zero, but it is not very precisely estimated. It suggests that the typical acquiring bank brings the acquired part of the consolidated bank an estimated $30 \%$ of the way toward its own pre-merger efficiency rank. We temporarily defer discussion of the other variables in the regression.

In the second column of Table 3, we examine the Low Efficiency Hypothesis, which emphasizes the potential for improvement when either or both of the acquirer and acquired are inefficient. The variables W1(EFF1) and W2(EFF2) replace W2(EFF1-EFF2) in (3), so that the efficiency ranks of acquiring and acquired banks are weighted by their respective importance to the consolidated firm. The statistically significant negative coefficients of -.55 and -.72 on W1(EFF1) and W2(EFF2), respectively, are consistent with the predictions of the Low Efficiency Hypothesis -- the merger efficiency gains appear to be greater when there is more room for the improvement of both the acquirer and acquired. The adjusted $\mathrm{R}^{2}$ of this regression is also improved relative to the prior equation (rising from .71 to .78 ), further suggesting that the ex ante efficiencies of both the acquirer and acquired are important, rather than just their difference.

The third column of Table 3 shows a complete regression with both hypotheses represented. The 
results provide strong, statistically significant support for both hypotheses. The positive significant coefficient of .48 on W2(EFF1-EFF2) is consistent with the Relative Efficiency Hypothesis and the negative significant coefficient of -.63 on W1(EFF1) is consistent with the Low Efficiency Hypothesis. The -.17 coefficient on W2(EFF2) is small and statistically insignificant, which may in part reflect the very high collinearity among the regressors in this equation. It is perhaps surprising that any of the important parameters are significant, given that EFF1 and EFF2 both appear twice in the three main variables and W2 appears in all three main variables (recall that W1 1 1-W2) and is also represented a fourth time as a stand-alone variable. The adjusted $\mathrm{R}^{2}$ of this regression is also the highest, .80 , suggesting that both of the hypotheses add independent information that helps predict future efficiency improvements. These results also suggest that merger efficiency success can be fairly well predicted, given that about $80 \%$ of the variance of ex post profit efficiency gains can be explained with the ex ante variables specified here.

The success of the profit efficiency model here contrasts sharply with earlier cost efficiency models, which were generally unsuccessful in identifying ex ante hypotheses and conditions that accurately predict merger efficiency gains. For example, Berger and Humphrey (1992) used the same data set and many of the same variables and were able to explain less than $30 \%$ of the variance of the cost efficiency gains from mergers and found many estimated coefficients to have signs that were contrary to the predictions of the hypotheses. ${ }^{34}$

${ }^{34}$ One cost efficiency analysis, DeYoung (1996), did find several variables to be significantly related to merger cost efficiency gains on the basis of bivariate comparisons. However, because many of these variables are highly correlated with one another, not all of the results were robust to multiple regression analysis as we use here. A separate regression analysis supplied to us by the author but not included in his original paper suggested that mergers of relatively inefficient banks, regulator-assisted mergers of insolvent banks, and acquisitions by banks that made repeat purchases were statistically significantly more likely to increase cost efficiency post-merger than other mergers. The other efficiency gains suggested by the bivariate analyses -- those associated with the relative sizes of the merger partners, the relative efficiency ranks of the partners, and the holding company status of the partners -- were not statistically significant in the regression analysis. Overall, the variables explained only 23 percent of the variance of the cost efficiency gains. By way of comparison, we also tried examining the profit efticiency gains 
In order to get a better feel for the effects of the two ex ante efficiencies and how well the two main hypotheses work, we also examine the derivatives of the dependent variable with respect to EFF1 and EFF2. The estimated marginal effect of EFF1 is . $48 \bullet \mathrm{W} 2-.63 \bullet \mathrm{W} 1$, which is almost always negative since $\mathrm{W} 1$ is generally larger than $\mathrm{W} 2$. Evaluated at the average value of $\mathrm{W} 2=.28$, this partial derivative is $\mathbf{- . 4 0}$. This suggests that for a merger in which the relative sizes of the merging banks is typical, if the efficiency rank of the acquiring bank is 10 percentage points lower, the merger is predicted to raise profit efficiency by an additional 4 percentage points, all else equal. The estimated marginal effect of EFF2 is $.48 \bullet(-W 2)-.17 \bullet W 2=-.65 \bullet W 2$. Evaluated under the same conditions as EFF1, this partial derivative is -.18 and suggests that if the efticiency rank of the acquired bank is 10 percentage points lower, the merger is predicted to raise efficiency by an additional 1.8 percentage points. Thus, the results suggest that mergers are likely to improve efficiency more, the lower is the efficiency of both the acquiring and acquired bank, with a larger marginal effect from the acquiring bank. The effect of the lower efficiency of the acquiring bank is consistent with the Low Efficiency Hypothesis that the merger "wakes up" bank management and/or gives it an excuse to take significant actions to improve performance. However, the effect of the lower efficiency of the acquired bank appears to reflect primarily the Relative Efficiency Hypothesis, in which lower acquired bank efficiency leaves more room for improvement as the acquired part of the bank moves toward the efficiency rank of the acquired part.

The coefficients of the control variables in the three efficiency improvement equations are mostly statistically insignificant. The only control variable coefficient that is significant in the fully specified equation in the third column of Table 3 is the negative parameter on RETAIL. This suggests that banks that receive more of their funds through retail deposits at bank branches are less likely to make efficiency improvements through mergers, contrary to expectations about cost savings through branch

by repeat acquirers and found that such acquirers generally had lower profit efficiency gains on average than other acquirers, likely because the ex ante efficiencies of the firms involved in their mergers were already much higher than other mergers (.85 versus .71$)$. 
consolidations. Similarly, having branches in overlapping markets (OVERLAP) does not appear to predict efficiency improvements, and is significantly negative in the first estimation. A larger scale of operations for the merging banks (SCALE) consistently predicts a merger efficiency loss, although it is only significant in the first estimation. All of the other control variables (W2, STINCOME, HERF, SHARE) are either statistically insignificant or have conflicting signs across estimations. The general ineffectiveness of most of the control variables in predicting profit efficiency gains from mergers is consistent with Berger and Humphrey's (1992) results for predictions of cost efficiency gains for these same mergers.

The full regression specification is repeated in the last two columns of Table 3, using the changes in the profitability ratios $\triangle \mathrm{ROA}^{\mathrm{a}}$ and $\triangle \mathrm{ROE}^{\mathrm{a}}$ as the dependent variables. As discussed above, the changes in these profitability ratios are likely less accurate indicators of efficiency than are the improvements in the profit efficiency ratio $\Delta\left(\pi / \pi^{\circ}\right)$ and the profitability ratios may also incorporate the effects of price changes associated with increases in market power. As shown, none of the coefficients for testing the Relative Efficiency Hypothesis or the Low Efficiency Hypothesis is statistically significant, although the coefficients of W2(EFF1-EFF2) and W1(EFF1) do have the same signs as in the complete $\Delta\left(\pi / \pi^{\circ}\right)$ specification in the third column. The only statistically significant coefficients in the profitability ratio regressions are on STINCOME, suggesting that mergers in states with booming economies prior to the merger do not improve earnings as much as other mergers. As discussed above, the expectations for the sign of this variable depend upon whether regions with high ex ante growth continue to grow at a higher rate or lower rate after the merger. To investigate this further, we examined the behavior of STINCOME for merger participants before and after mergers relative to the average state personal income growth for the nation as a whole. Prior to mergers, STINCOME was 58 basis points below the national average ( $1.86 \%$ for merging banks versus $2.44 \%$ nationally) and fell to 120 basis points below the national average post-merger, for a relative decline of 62 basis points. The correlation 
between the pre-merger deviation from the national average and the post-merger deviation is a statistically insignificant .14. That is, megamergers tended to take place in states with slightly lower than average income growth, this disadvantage increased after mergers, and the current state income growth is a poor predictor of future growth. This partial analysis does not explain why STINCOME has statistically significant negative coefficients in the $\triangle \mathrm{ROA}^{\mathrm{a}}$ and $\triangle \mathrm{ROE}^{\mathrm{a}}$ regressions, but it does suggest why a high growth rate prior to merger does not necessarily predict the ex post success of consolidating banks, given that high rates of growth will not necessarily continue. The analysis below will suggest another reason for the importance of the STINCOME variable here -- it is correlated with the bank's prices, and inclusion of these prices will substantially reduce the measured effect of STINCOME.

The adjusted $\mathrm{R}^{2} \mathrm{~s}$ of three regressions are also relatively low, .09 and .17 for $\mathrm{ROA}^{\mathrm{a}}$ and $\mathrm{ROE}^{\mathrm{a}}$, respectively, suggesting that changes in the profitability ratios are difficult to predict. Most of the variance that is explained is owing to the regional business conditions -- the adjusted $R^{2}$ s fall to .02 or less when STINCOME is excluded (not shown). Thus, neither of the main hypotheses nor most of the variables were very successful in predicting the profitability outcomes of mergers, even though they did predict profit efficiency gains fairly well.

\section{The Market Power Effects on Prices of Megamergers}

In this section, we analyze the price effects associated with megamergers, the effects of these price changes on bank profits, and evaluate whether various ex ante factors can predict these price changes. The analysis follows along the same lines, uses many of the same variables, and tests hypotheses that are very similar to the foregoing examination of the efficiency changes. Thus, we follow the same specifications of netputs for the same data set, etc., as in the foregoing efficiency analysis, so that market power and efficiency implications of megamergers can be properly compared. We recognize and acknowledge, however, that the netput categories are rather broad and the prices calculated from Call Report information are less precise than the survey prices on more detailed categories of bank deposits 
and loans cited in the literature review above. ${ }^{35}$ Thus, we forego some accuracy to gain comparability with the efficiency findings. We also acknowledge that any findings on market power effects must be interpreted as partially reflecting the outcome of antitrust policy, which is intended to thwart substantial increases in market power associated with mergers through the approval/denial process.

The Changes in Prices Associated with Mergers. We confine our analysis of price changes to the prices of loans and deposits, our first and third netputs. The prices of these products have been found to be related to local market concentration in ways consistent with the exercise of market power (see literature review above). In contrast, the markets for securities and labor, the other two variable netputs, are likely too large for banks to exert any significant market power in setting prices.

Table 4 shows the changes in loan and deposit price premiums associated with mergers. Since interest rates and aggregate risk conditions change so greatly over time, we express each of the prices as the deviation from the mean price of the peer group of large banks with data available over the same time period $\left(\mathrm{p}-\mu_{\mathrm{p}}\right)$. This is similar to our treatment of efficiencies as ranks relative to the peer group distributions above. As shown in the first row of Table 4, merging banks charged about 17 basis points more on loans than the average large bank prior to merging, and charged a premium over the average of only about 10 basis points after merging, a fall in the average premium of about 7 basis points. This change in premium is quite small and is not significantly different from zero. Although this negative effect on loan price is contrary to expectations about increases in market power, it does not entirely rule out an increase in market power in setting prices, since price changes may reflect changes in efficiency and other market dynamics as well as changes in market power. For example, the small decrease in price could represent some of the efficiency gains being competed away and distributed to loan customers as

${ }^{35}$ Prices paid are not given on the Call Report. Our constructed prices for the balance sheet netputs, loans, securities, and deposits, are simply the flow of net interest and fees received (loans, securities) or paid (deposits) during the year divided by the reported balance sheet quantity at the end of the year. 
consolidated banks expand their loan portfolios. Similarly, mergers may create better diversification of loan portfolios across geographic markets and/or industries, which may allow the consolidated banks to reduce their average risk premium charged to loan customers. Consolidated banks might also purposely lower their loan rates slightly in order to compete more aggressively for loan market shares. The finding given above that merging banks increase their loan/total asset ratios is consistent with these speculations. In any event, it appears unlikely that there are many substantial increases in the exercise of market power in setting loan prices that are higher than they otherwise would be. If anything, loan customers of merging banks appear to be made slightly better off by receiving more credit at perhaps a slightly lower price. $^{36}$

The deposit premium data show a small, statistically insignificant fall in price subsequent to megamergers, from an average premium of about 73 basis points to about 66 basis points. Unlike the loan prices, however, this price change is unfavorable to consumers of banking services and may represent an increase in market power that raises bank profits. This may also in part reflect a movement of the prices of the acquired parts of the consolidated firms toward their acquiring parts'prices, since on average acquiring banks have lower deposit prices than acquired banks.

The figures in the bottom panel of Table 4 translate the loan and deposit premium changes into changes in profitability. We multiply the changes in premiums by the pre-merger quantities of loans and deposits and divide by three different denominators -- pre-merger potential profits, total assets, and equity. The three denominators match those used above when evaluating efficiency changes, except that we hold these denominators, as well as the loan and deposit quantities, at the pre-merger levels. The purpose of using the pre-merger quantities is to get as close as possible to the pure market power effects

\footnotetext{
${ }^{36} \mathrm{We}$ also acknowledge the possibility of measurement error accounting for the change in loan price, as could occur if there were a substantial shift in the type or duration of loans issued.
} 
of mergers. The post-merger quantities would be confounded by the changes in efficiency. ${ }^{37}$

The findings suggest a very small and inconsistent effect of market power. The change in profits/potential profits from the change in prices, $\Delta \mathrm{p} \bullet \mathrm{q} / \pi^{\circ}$, is less than 3 basis points of potential profits. Moreover, the effect turns slightly negative when total assets or equity is used as the denominator.

In order to compare the effects of the price changes with the efficiency changes described in the previous section, we tried adding these extra profits from price changes to the changes in predicted profits from efficiency gains. We found that the price effects were dwarfed by the efficiency changes. Adding the profits from price changes to the numerator of the ex post efficiency ratio $\mathrm{m} / \mathrm{TO}$ left the rank essentially unchanged at .90 . That is, merging banks increased their predicted profit/potential profit ratio from the 74th percentile to the 90th percentile on the basis of improvements in profit efficiency, and the addition of changes in profits from price changes moved the rank by less than one percentile. ${ }^{38}$ In sum, the average changes in prices due to market power and other influences are small(less than 7 basis points each), the effects on loan prices and deposit prices tend to offset each other leaving a very small average net effect on profits, and this profit effect is almost immeasurably small compared to the change in profits from improvements in profit efficiency.

The very small effect of market power from bank megamergers here should perhaps not be too surprising. One reason is that the megamergers of the 1980s were often of the market extension variety with little or no local market overlap, often in response to removal of interstate banking barriers. Only

\footnotetext{
${ }^{37}$ The true change in profits from changing prices would also include the second-order effects from the quantities of loans and deposits changing as consumers reacted to these price changes. However, without explicit demand and supply functions for bank netputs, there is no way to take these additional effects on profits into account. However, it seems likely that these neglected effects on profits would be very small, since they depend on the changes in quantities times the difference between price and marginal cost or marginal revenue.

${ }^{38}$ The actual measured change in $\pi / \pi^{\circ}$ rank from adding price effects was a slight decrease from the 90.0 percentile to the 89.9 percentile. Thus, although the level of r/TO increased on average by about 3 basis points, the decreases in profits more often resulted in a change in $\pi / \pi^{\circ}$ rank than the increases in profits.
} 
within-market mergers with considerable local market overlap would be expected to result in substantial increases in local market concentration and market power. Second, antitrust policy in the form of merger denials or requirements for divestiture is intended to block or alter merger arrangements that are likely to result in substantial increases in market power by limiting the amount by which local market concentration can increase.

The data on the actual changes in local market concentration are consistent with these arguments. ${ }^{39}$ For the 57 megamergers as a whole, the value of the weighted average local market Herfindahl index (HERF) increases on average by .0045 or 45 points as it is usually quoted. This is well below the 200 points allowed for bank mergers. However, note that we are using the actual value of HERF after the merger, inclusive of the changes in behavior of the consolidated firm and its market rivals in the years after the merger, whereas antitrust authorities base their decisions on information available prior to mergers on the change in HERF if there in no change in behavior after the merger. As expected, the increase in HERF for the 40 megamergers in which there is positive local market overlap is 62 points, considerably more than the 6 point increase for the 17 megamergers with no overlap. We also find that for the 18 megamergers in which market overlap is over $\mathbf{5 0 \%}$, the increase in HERF is still quite modest, 53 points, suggesting a strong influence of antitrust policy for mergers which are mostly within-market. It is also notable that the average pre-merger value of HERF for firms with overlap over $50 \%$ is only 1544, well below the mean, suggesting that antitrust authorities are generally successful in preventing mergers with substantial overlap in markets with high concentration..$^{40,41}$

\footnotetext{
${ }^{39}$ For the purpose of examining changes in market concentration, we do not subtract off peer group means as in the rest of the analysis, because antitrust policy generally does not consider concentration in markets other than those of the merger participants.

${ }^{40}$ The data on the weighted average change in local market share (SHARE) are consistent with the HERF findings. The increase in SHARE for consolidating firms is $1.1 \%$ overall, $-1.4 \%$ for firms with no overlap, $2.1 \%$ for firms with some overlap, and $3.3 \%$ for firms with over $50 \%$ overlap.
} 
Sources of Profit Improvement from Price Changes. Just as it was important for antitrust policy purposes to know if there are any identifiable ex ante conditions that are good predictors of efficiency improvements, it is equally important to know if any increase in market power in price setting can be predicted. Although the average change in price is small, it is still possible that there are substantial individual price changes that can be predicted.

The analysis here follows directly from the analysis of efficiency improvements above. The dependent variable is the increase in profits from price changes normalized by potential profits just discussed, $\Delta \mathrm{p} \bullet \mathrm{q} / \pi^{\circ}$. The ex ante variables used to predict the price-related changes in profits include all of the variables employed above to predict efficiency gains, since efficiency gains may also affect prices. We also include some additional ex ante variables to test the Relative Price Hypothesis and the Low Price Hypothesis, , price-based theories that are analogous to the two efficiency hypotheses tested above. These additional variables are shown in Table 5.

Under the Relative Price $\underline{\text { Hypothesis}}$, the acquiring bank brings the prices of the acquired bank towards its own level. The variable V2(P1-P2) Loan is the weighted difference in price between the loans of the acquiring and acquired bank, where the weight measures the relative importance of the acquired bank's loans $\left(\mathrm{V} 2_{\text {Loan }} \equiv(\text { Loans2/(TA1+TA2)). Similarly, V2(P1-P2) })_{\text {Dep }}\right.$ measures the weighted price difference for deposits, using the deposit relative weight.. Because deposit prices are paid by rather than received by the bank, we enter this variable in the regression with a minus sign. Under these conditions, both variables have positive predicted coefficients.

Under the Low Price Hypothesis, either acquiring or acquired banks with lower loan prices have more room for raising prices through the merger process. The merger may create the possibility of increasing prices through higher market concentration. Mergers might also "wake up" management to

\footnotetext{
${ }^{41}$ As corroborating evidence, Berger, Kashyap, and Scalise (1995) also found that HERF and SHARE did not change very much with liberalizations of intrastate and interstate banking rules in the 1980s and first half of the 1990s.
} 
the possibility of exploiting market power opportunities, or give managers an "excuse" on which to blame price increases to customers. The variables V1(P1) Loan, $\mathrm{V} 2(\mathrm{P} 2)_{\text {Loan }},-\mathrm{V} 1(\mathrm{P} 1)_{\text {Dep }}$, and $-\mathrm{V} 2(\mathrm{P} 2)_{\text {Dep }}$ are weighted prices, and should have negative coefficients under the Low Price Hypothesis as firms with lower loan prices or higher deposit prices ex ante can generally improve their profits more. ${ }^{42}$

Table 6 shows the regression results using the normalized change in profits from price changes $\Delta \mathrm{p} \bullet \mathrm{q} / \pi^{\circ}$ as the dependent variable. We include all the variables used above to predict efficiency gains, since changes in efficiency are likely to affect prices. We also show regressions with $\triangle \mathrm{ROA}^{\mathrm{a}}$ and $\Delta \mathrm{ROE}^{\mathrm{a}}$ as dependent variables using the full specification of efficiency and market power ex ante variables. These should be considered to be the more complete equations for the profitability ratios.

The findings in Table 6 do not support the Relative Price Hypothesis. The data suggest that acquiring firms do not appear simply to adjust the prices of the acquired firms toward their own..$^{43}$ The data do, however, provide some support for the Low Price Hypothesis, at least with regard to the prices of the acquired firm. ${ }^{44}$ This suggests that mergers facilitate the exercise of market power or "wake up" management to raise low loan prices or reduce high deposit prices of the acquired part of the consolidated bank..$^{45}$

\footnotetext{
${ }^{42}$ For completeness, we also specify the acquiring and acquired firms' loan and deposit share weights, $\mathrm{V} 1_{\text {Loan }}, \mathrm{V} 1_{\text {Dep }}, \mathrm{V} 2_{\text {Loan }}$, and $\mathrm{V} 2_{\text {Dep }}$. Inclusion of these terms assure that the main variables of interest -. which are interactions of these weights with the ex ante prices -- do not unintentionally reflect any excluded effects of the weights themselves.

${ }^{43}$ In the main regression with $\Delta \mathrm{p} \bullet \mathrm{q} / \pi^{\circ}$ as the dependent variable, the coefficients of the V2(P1-P2) Loan and -V2(P1-P2) $)_{\text {Dep }}$ variables are both negative, with the loan price effect statistically significant. The negative sign is contrary to the predictions of the theory. Moreover, the coefficients of these variables in the profitability ratio regressions are also all negative.
}

${ }^{44}$ The coefficients of V2(P2) $)_{\text {Loan }}$ and $-\mathrm{V} 2(\mathrm{P} 2)_{\mathrm{Dep}}$ have the predicted negative signs and are statistically significant in the $\Delta \mathrm{p} \bullet \mathrm{q} / \pi^{\circ}$ regression. The V2(P2) Loan coefficients are also negative and significant in the $\triangle \mathrm{ROA}^{\mathrm{a}}$ and $\triangle \mathrm{ROE}^{\mathrm{a}}$ regressions.

${ }^{45}$ The coefficients for the acquiring banks' prices, V1(P1) Laan $_{\text {and }}$-V1(P1) $)_{\text {Dep }}$, are much smaller, not statistically significant, and one of them has the wrong sign. However, this "non-result" could in part reflect the fact that these prices already appeared in the equation in the price difference terms V2(P1- 
We also compute the estimated derivatives of the price-related change in profits with respect to the ex ante prices, similar to our earlier analysis of efficiency effects. The estimated marginal effect of $P 1_{\text {Loan }}$, the loan price of the acquirer, is $-5.99 \bullet \mathrm{V} 2_{\text {Loan }}+0.39 \bullet \mathrm{V} 1_{\text {Loan }}$, which equals -0.65 at the mean values of the weights (.33 and .13 for $V 1_{\text {Loan }}$ and $V 2_{\text {Loan }}$, respectively). Thus, an acquiring bank with an average loan price 1 percentage point lower ex ante is predicted to have an increase in profits from repricing of almost an additional 2/3 of 1 percent of maximum profits. Similarly, the marginal effects of $P 2_{\text {Loan }}, P 1_{\text {Dep }}$, and $P 2_{\text {Dep }} P 1$ are $-0.52,0.23$, and 0.03 , respectively at the mean, suggesting greater profits from merger-related repricing when loan prices are relatively low or deposit prices are relatively high before the merger.

The policy inference from these findings is that the exercise of market power in price setting is at least partially predictable from ex ante conditions. It appears that either acquiring or acquired firms that have low loan prices or high deposit prices ex ante may be good candidates for the exercise of market power in changing prices after a merger. Although the average change in profits from repricing is very small, substantial effects may be predicted in some individual merger cases.

Turning to the $\triangle \mathrm{ROA}^{\mathrm{a}}$ and $\triangle \mathrm{ROE}^{\mathrm{a}}$ regressions, a surprising result is the strength of the ex ante price terms in predicting changes in profitability. Two of the coefficients of the price variables are statistically significant in the $\triangle \mathrm{ROA}^{\mathrm{a}}$ equation, eliminating the significance of the STINCOME variable (which was the only significant variable in the equation in Table 3), and almost doubling the adjusted $\mathrm{R}^{2}$ from .09 to .16. The ex ante price variables are also important, although less dramatically so, in the $\Delta \mathrm{ROE}^{\mathrm{a}}$ equation. These results -- which suggest that the profitability ratios respond more to ex ante prices than ex ante efficiencies -- justify our earlier concern that these ratios confound the effects of efficiency and market power and may partially explain why the profitability ratios appear to be very

P2) $)_{\text {Loan }}$ and -V2(P1-P2) $)_{\text {Dep }}$ with theoretically incorrect negative signs on their coefficients. Since it is implausible that the acquiring firms would generally adopt the pricing policies of the acquired firms, it is possible that these price difference terms might be reflecting Low Price Hypothesis effects. 
sensitive to changes in efficiency only when the efficiency changes are large.

\section{Conclusions}

Mergers can potentially improve profits by increasing cost efficiency, profit efficiency, or market power. Prior analyses of bank mergers have focused on cost efficiency and found that these mergers typically do not succeed in significantly reducing unit costs. However, there have been no academic studies of profit efficiency effects and very few studies of the market power effects of bank mergers. Prior studies of bank profitability ratios, such as return on assets or return on equity, may confound the effects of profit efficiency changes with changes in the exercise of market power, since either can increase profitability. There has also been little success in identifying ex ante conditions that predict changes in efficiency or the exercise of market power for use in antitrust policy. If specific conditions can be determined that reasonably accurately predict when mergers are likely to result in gains in efficiency or increases in the exercise of market power, the merger approval/denial process might be improved.

The purpose of this paper is to provide some evidence on these remaining questions. We investigate both the profit efficiency and market power effects of mergers and try to identify ex ante conditions that predict when either is likely to be increased. We also compare the effects of efficiency and market power, and show the important differences between cost efficiency and profit efficiency.

Our findings suggest that the banking megamergers of the 1980s did significantly improve profit efficiency on average. The average profit efficiency rank of merging banks increased from the 74th percentile to the 90th percentile of the peer group of large banks with complete data available over the same time intervals, a statistically significant 16 percentage point increase. Use of profit efficiency levels, rather than ranks, indicated similar improvements. This main result was also robust to the alternative 'nonstandard' specification of the profit function which likely removes any scale or merger biases from the analysis.

These profit efficiency findings might at first blush appear to conflict with the prior literature that 
generally found no cost efficiency improvements associated with mergers, including a study that used the same data set as the current inquiry. However, the reason for the different findings is quite simple. Measured cost efficiency changes do not take into account the effects of the changes in output that occur after the merger, whereas measured profit efficiency changes include all the cost efficiency changes plus the cost and revenue effects of changes in output that typically occur after a merger. In our data set, merging banks tend to shift their output mixes from securities toward loans, which raises profit efficiency because issuing loans creates more value than purchasing securities. Under the Diversification Hypothesis, this shift in mix may occur because merging banks have improved diversification of risks that allow a higher loan/asset ratio. This shift appears to occur without any increase in the equity/asset ratio (which in fact declines slightly), supporting the Diversification Hypothesis, since capital markets typically restrict banks from taking substantial additional risks without increases in equity. Also supporting the Diversification Hypothesis are the findings by Benston, Hunter, and Wall (1995) that acquiring banks tend to bid more to acquire safer banks and the finding by Hughes, Lang, Mester, and Moon (1996) that larger banking organizations are able to shift the risk-expected return frontier. In any case, we argue that this increase in the value of output produced is just as beneficial to society as a decrease in costs of the same magnitude, and helps demonstrate why profit efficiency is the more appropriate concept to consider for evaluating mergers than is cost efficiency alone.

Our prediction model for profit efficiency improvements based on ex ante information available prior to the merger appears to be fairly successful. The ex ante variables explain about 80 percent of the variance of the ex post change in profit efficiency rank. Moreover, the model results also support two theories about the conditions that are likely to result in profit efficiency improvement. Under the

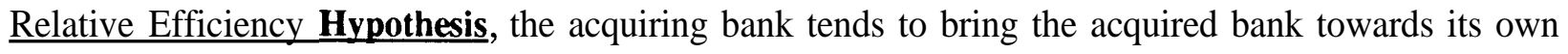
level of efficiency, so that larger ex post merger efficiency gains are predicted, the greater is the difference in ex ante efficiency between the acquiring bank and acquired bank. Under the Low 
Efficiency Hypothesis, the ex post improvement in efficiency after the merger is higher if either or both of the merging firms have low ex ante efficiency prior to the merger. Here, the merger event itself may have the effect of "waking up" management or be used as an "excuse" to implement substantial restructuring or other changes to improve efficiency.

The data provide some support for both of these theories and generally predict greater merger efficiency gains when either or both merging firms have poor performance prior to the merger. Evaluated at the mean of the data, if the efficiency rank of the acquiring bank is 10 percentage points lower, the predicted gain in ex post efficiency rank for the consolidated bank is about 4 percentage points higher. Similarly, if the acquired bank is 10 percentage points worse in rank, the predicted gain in rank for the consolidated bank is about 1.8 percentage points higher than it would otherwise be.

In addition, the loan/asset ratios of the merging firms may be used to predict profit efficiency improvements even if direct measures of profit efficiency are not available. A weighted average loan/asset ratio of the merging firms in the bottom third of the sample distribution prior to merger predicts an additional 7 percentage point improvement in profit efficiency rank relative to merging firms with loan/asset ratios in the highest third without using any other variables. This is because a low loan/asset ratio reflects low profit efficiency and a greater capacity to improve after the merger.

In contrast to the profit efficiency findings, the price changes on loans and deposits that occur following mergers are considerably smaller and harder to predict. On average, both loan and deposit prices fall on average (relative to the peer group average) by less than 7 basis points, neither of which are statistically significant. We acknowledge that these prices likely embody significant amounts of measurement error because the loan and deposit categories are so broad and because these prices are calculated from balance sheet ratios rather than from survey information on prices actually paid. Although price changes may incorporate the effects of efficiency, measurement error, and other factors as well as changes in market power, it seems fairly likely that on average the market power effects of 
megamergers in banking are very small. The loan and deposit price changes tend to offset each other in their effects on profits, and the profit effects from price changes are almost immeasurably small relative to the profit effects from efficiency changes. As well, the changes in local market concentration from megamergers is quite small on average $(\triangle \mathrm{HERF}=45$ points $)$, even for mergers between banking organizations with substantial market prior to merger $(\triangle \mathrm{HERF}=\mathbf{5 3}$ points $)$. These data are consistent with the hypothesis that antitrust policy has been successful in preventing mergers that would bring about large increases in concentration and market power, but it not known whether this policy may have also prevented some mergers that might have increased efficiency substantially.

Tests of two price-based theories analogous to the efficiency hypotheses suggested some conditions that help predict when price changes from individual mergers are likely to be substantial. Mergers in which either or both of the merging firms have very low loan prices or very high deposit prices are good candidates for increased exercise of market power in setting prices less favorable to consumers on loans and/or deposits after merging.

We also examined the effects of bank megamergers on more standard measures of profitability, such as the adjusted returns on assets and equity. The ex post changes in these profitability ratios should embody some of the effects of both profit efficiency and price changes from exercise of market power. These profitability ratios appear to be the most difficult to predict and to be more sensitive to changes in market power than changes in profit efficiency. However, these profitability ratios do appear to reflect the profit efficiency changes when the efficiency changes are most pronounced, such as when the ex ante efficiencies of the merging banks are relatively low.

We close with several caveats about drawing strong inferences from this single study of the profit efficiency and market power effects of bank megamergers. First, our measurement of profit efficiency applied a very parsimonious specification of bank inputs and outputs because of the difficulty of estimating a nonlinear system with cross-equation restrictions. It is quite possible that important shifts 
in outputs or inputs took place within these broad categories. Second, our price data are less precise than are the survey prices on more detailed categories of bank deposits and loans often used in the literature. A better study of market power effects of mergers alone would use the survey prices and also control for the efficiency effects of mergers. However, because survey price information is limited, such a study could not be confined to megamergers only. Finally, our results may not necessarily generalize to mergers other than the banking megamergers of the 1980s that make up our data set. It is possible that greater cost efficiency gains may be present in other industries or in bank mergers of the 1990s because of an increased focus on cost savings in the current decade. Similarly, there may be more market power effects on prices in mergers of smaller banks, which tend to occur in more concentrated local markets. 


\section{REFERENCES}

Akhavein, Jalal D., P. A.V.B. Swamy, and Steven B. Taubman, "A General Method of Deriving the Efficiencies of Banks from a Profit Function," Working Paper, Wharton Financial Institutions Center, University of Pennsylvania (October 1994).

Aly, Hassan Y., Richard Grabowski, Carl Pasurka, and Nanda Rangan, "Technical, Scale, and Allocative Efficiencies in U.S. Banking: An Empirical Investigation, " Review of Economics and Statistics, 72 (1990): 211-18.

Asquith, P., and H. Kim, "The Impact of Merger Bids on the Participating Firm's Security Holders," Journal of Finance, 38 (June 1983): 813-26.

Benston, George J., William C. Hunter, and Larry D. Wall, "Motivations for Bank Mergers and Acquisitions: Enhancing the Deposit Insurance Put Option versus Earnings Diversification," Journal of Money, Credit, and Banking, 27 (August 1995): 777-88.

Berger, Allen N., "'Distribution-Free' Estimates of Efficiency in the U.S. Banking Industry and Tests of the Standard Distributional Assumptions," Journal of Productivity Analysis 4 (September 1993): 261-92.

Berger, Allen N., "The Profit-Structure Relationship in Banking -- Tests of Market-Power and EfficientStructure Hypotheses," Journal of Money, Credit, and Banking, 27 (May 1995a): 404-31.

Berger, Allen N., "The Relationship Between Capital and Earnings in Banking," Journal of Money, Credit, and Banking, 27 (May 1995b): 432-56.

Berger, Allen N., J. David Cummins, and Mary A. Weiss, "The Coexistence of Multiple Distribution Systems for Financial Services: The Case of Property-Liability Insurance, " working paper, Wharton Financial Institutions Center, University of Pennsylvania (July 1995).

Berger, Allen N., Diana Hancock, and David B. Humphrey, "Bank Efficiency Derived from the Profit Function," Journal of Banking and Finance 17 (April 1993):317-47.

Berger, Allen N., and Timothy H. Hannan, "The Price-Concentration Relationship in Banking, "Review of Economics and Statistics, 71(May 1989): 291-299.

Berger, Allen N., and Timothy H. Hannan, "The Efficiency Cost of Market Power in the Banking Industry: A Test of the 'Quiet Life' and Related Hypotheses, " Working Paper, Board of Governors of the Federal Reserve System (November 1995).

Berger, Allen N., and Timothy H. Hannan, "Using Measures of Firm Efficiency to Distinguish among Alternative Explanations of the Structure-Performance Relationship," Managerial Finance,(1996).

Berger, Allen N., and David B. Humphrey, "Megamergers in Banking and the Use of Cost Efficiency as an Antitrust Defense, " Antitrust Bulletin 37 (Fall 1992): 541-600.

Berger, Allen N., David B. Humphrey, and Lawrence B. Pulley, "Do Consumers Pay for One-Stop 


$$
\mathrm{R}-2
$$

Banking? Evidence from an Alternative Revenue Function, " Working Paper, Department of Finance, Florida State University, Tallahassee, FL (November 1995).

Berger, Allen N., William C. Hunter, and Stephen G. Timme, "The Efficiency of Financial Institutions: A Review and Preview of Research Past, Present, and Future, "Journal of Banking and Finance, 17 (April 1993): 221-49.

Berger, Allen N., Anil K Kashyap, and Joseph M.Scalise, "The Transformation of the U.S. Banking Industry: What A Long, Strange Trip It's Been," Brookings Papers on Economic Activity (2:1995).

Cornett, Marcia M., and Hasan Tehranian, "Changes in Corporate Performance Associated with Bank Acquisitions, "Journal of Financial Economics 31(1992): 211-34.

Demsetz, Harold, "Industry Structure, Market Rivalry, and Public Policy, "Journal of Law and Economics 16(1973):1-9.

DeYoung, Robert, "Bank Mergers, X-Efficiency, and the Market for Corporate Control, "Managerial Finance, (1996).

DeYoung, Robert, and Daniel E. Nolle, "Foreign-Owned Banks in the U.S.: Earning Market Share or Buying It," working paper, Office of the Comptroller of the Currency, Washington, DC.1995.

English, Mary, Shawna Grosskopf, Kathy Hayes, and Suthathip Yaisawarng, "Output Allocative and Technical Efficiency of the Financial Services Sector," Journal of Banking and Finance 17 (April 1993): 349-66.

Ferrier, Gary D., and C.A. Knox Lovell, "Measuring Cost Efficiency in Banking: Econometric and Linear Programming Evidence," Journal of Econometrics, 46(1990):229-45.

Fixler, Dennis J., and Kimberly D.Zieschang, "An Index Number Approach to Measuring Bank Efficiency: An Application to Mergers," Journal of Banking and Finance 17(April1993): 43750.

Hannan, Timothy H., "Bank Commercial Loan Markets and the Role of Market Structure: Evidence from Surveys of Commercial Lending," Journal of Banking and Finance, 15 (February 1991):133-149.

Hannan, Timothy H., and Robin A. Prager, "Do Substantial Horizontal Mergers Generate Significant Price Effects? Evidence from the Banking Industry, "Working Paper, Board of Governors of the Federal Reserve System, Washington, DC (November 1995).

Houston, Joel F., and M.D. Ryngaert, "The Overall Gains from Large Bank Mergers, " Journal of Banking and Finance, 18 (December 1994):1155-76.

Hughes, Joseph P., William Lang, Loretta J. Mester, Choon-Geol Moon, "Efficient Banking Under Interstate Branching," Journal of Money, Credit and Banking, 28(1996).

Kim, Han, and John McConnell, "Conglomerate Mergers and the Co-Insurance of Corporate Debt," 


$$
\mathrm{R}-3
$$

Journal of Finance, 32 (March 1977):349-65.

Kim, E. Han, and Vijay Singal, "Mergers and Market Power: Evidence from the Airline Industry," American Economic Review 83(June 1993):549-69.

Linder, Jane C. and Dwight B.Crane, "Bank Mergers: Integration and Profitability, " Working paper, Harvard Business School, Cambridge MA (February 5,1992).

Peltzman, Samuel, "The Gains and Losses from Industrial Concentration, "Journal of Law and Economics 20 (1977): 229-63.

Peristiani, Stavros, "Do Mergers Improve the X-Efficiency and Scale Efficiency of U.S.Banks? Evidence from the 1980s," Working Paper, Federal Reserve Bank of New York, New York, NY (March 1995).

Pilloff, Steven J., "Performance Changes and Shareholder Wealth Creation Associated with Mergers of Publicly Traded Banking Institutions," Journal of Money, Credit, and Banking, 28(1996).

Rhoades, Stephen A., "Market Share as a Source of Market Power: Implications and Some Evidence," Journal of Economics and Business 37(1985):343-63.

Rhoades, Stephen A., The Operating Performance of Acquired Firms in Banking Before and After Acquisition, Staff Economic Studies 149, Board of Governors of the Federal Reserve System, Washington, DC (April 1986).

Rhoades, Stephen A., "Billion Dollar Bank Acquisitions: A Note on the Performance Effects," Working Paper, Board of Governors of the Federal Reserve System, Washington, DC (1990).

Rhoades, Stephen A., "The Efficiency Effects of Horizontal Bank Mergers," Journal of Banking and Finance 17 (April 1993): 411-22.

Rhoades, Stephen A., A Summary of Merger Performance Studies in Banking,1980-1993, and an Assessment of the "Operating Performance" and "Event Study" Methodologies, Staff Economic Studies 167, Board of Governors of the Federal Reserve System, Washington, DC (July 1994).

Savage, Donald T., "Mergers, Branch Closings, and Cost Savings, " Working Paper, Board of Governors of the Federal Reserve System, Washington, DC (November 1991).

Schmidt, Peter, and Robin C. Sickles, "Production Frontiers and Panel Data, "Journal of Business and Economic Statistics, 2 (October 1984):367-374.

Schrantz, Mary S., "Takeovers Improve Firm Performance: Evidence from the Banking Industry," Journal of Political Economy,101(April 1993): 299-326.

Sealey, Calvin, and James Lindley, "Inputs, Outputs, and a Theory of Production and Cost at Depository Financial Institutions, " Journal of Finance 32 (September 1977):1251-66.

Shaffer, Sherrill, "Can Megamergers Improve Bank Efficiency?" Journal of Banking and Finance 17 


$$
\mathrm{R}-4
$$

(April 1993): 423-36.

Shepherd, William G., "Tobin's q and the Structure-Performance Relationship:Comment," American Economic Review 76 (December 1986): 1205-1210.

Smirlock, Michael, "Evidence on the (Non)Relationship between Concentration and Profitability, "Journal of Money, Credit, and Banking, 17 (February 1985): 69-83.

Smirlock, Michael, Thomas Gilligan, and William Marshall, "Tobin's q and the Structure-Performance Relationship," American Economic Review, 74 (December 1984):1050-60.

Spindt, Paul A., and Vefa Tarhan, "Are There Synergies in Bank Mergers?," Working Paper, Tulane University, New Orleans, LA (November 1992).

Srinivasan, Aruna, "Are There Cost Savings from Bank Mergers?" Federal Reserve Bank of Atlanta Economic Review (March/April 1992):17-28.

Srinivasan, Aruna, and Larry D. Wall, "Cost Savings Associated with Bank Mergers, "Working Paper, Federal Reserve Bank of Atlanta, Atlanta GA (January 1992).

Toves, Alden, "Under What Circumstances Do Bank Mergers Improve Efficiency?" Proceedings of a Conference on Bank Structure and Competition, Federal Reserve Bank of Chicago, Chicago IL, 1992: 602-628.

U.S. Department of Justice and Federal Trade Commission, "Horizontal Merger Guidelines," April 2, 1992. 
Table 1: Changes in Profit Efficiency and Performance Rank from Megamergers

(1981-1989; Changes in ranks are in percentage points)

\begin{tabular}{cll} 
& \multicolumn{2}{l}{ Pre-Merger Rank; } \\
57 & Lowest & Highest \\
Mergers & 1/3rd & 1/3rd
\end{tabular}

\section{Profit Efficiency: $\pi / \pi^{\circ}$}

Pre-merger rank

Post-merger rank

Improvement in rank
.74

.90

$.16^{* *}$
.56

.83

$.27^{* *}$
.92

.95

$.03^{* *}$

Adiusted Return on Assets: $\mathrm{NI}^{\mathrm{a}} / \mathrm{TA}=\mathrm{ROA}^{\mathrm{a}}$

Pre-merger rank

Post-merger rank

Improvement in rank
.52

.57

.05

Adiusted Return on Equity: $\mathrm{NI}^{\mathrm{a}} / \mathrm{EQ}=\mathrm{ROE}^{\mathrm{a}}$

Pre-merger rank

Post-merger rank

Improvement in rank
.62

.65

.03
.50

.61

.47

.50

$.11^{*}$

.03

*(**) Improvement is statistically significantly different from zero at the $10 \%(5 \%)$ level, two-sided.

Note: The profitability ratios, $\mathrm{ROA}^{\mathbf{a}}$ and $\mathrm{ROE}^{\mathrm{a}}$, are adjusted to remove the 'noisy' fluctuations associated with loan loss provisions and taxes. 
Table 2: Ex Ante Variables Used to Predict Efficiency_Improvements

Variable:

Sample Mean

(Range)

W2(EFF1-EFF2): wt. difference in pre-merger profit efficiency rank

(using acquired bank's weight).

W1(EFF1): wt. pre-merger profit

efficiency rank of acquiring bank.

W2(EFF2): wt. pre-merger profit

efficiency rank of acquired bank.

W2: total asset size of acquired

bank relative to the size of the

acquirer plus acquired banks.

$.05 * *$

$(-.16, .17)$

$.58 * *$

$(.15, .96)$

$.16 * *$

$(.00, .57)$

$.28 * *$

$(.01, .73)$

$.34 * *$

$(0, .99)$

deposits in same local market.

STINCOME: average annual growth rate in state personal income.

HERF: wt. average Herfindahl index for merging banks.

$.019 * *$

$(-.006, .044)$

$.1850 * *$

$(.0800, .3628)$

$.21^{* *}$

$(.06, .45)$

share of merging banks.

$.69 * *$

$(.36, .93)$

ratio of merging banks.

SCALE: $w t$. average of pre-merger asset rankings for merging banks.
$.76^{* *}$

$(.40, .99)$

$*(* *)$ Mean is statistically significantly different from zero at the $10 \%(5 \%)$ level, two-sided. 
Table 3: Ex Ante Sources of Merger-Related Changes in Efficiency and Performance

(1981-1989; t-ratios in parentheses)

\begin{tabular}{|c|c|c|c|c|c|}
\hline & $\Delta\left(\pi / \pi^{\circ}\right)$ & $\Delta\left(\pi / \pi^{\circ}\right)$ & $\Delta\left(\pi / \pi^{\circ}\right)$ & $\triangle \mathrm{ROA}^{\mathrm{a}}$ & $\Delta \mathrm{ROE}^{\mathrm{a}}$ \\
\hline Intercept & $\begin{array}{l}.82^{* *} \\
(6.74)\end{array}$ & $\begin{array}{c}.71^{* *} \\
(5.24)\end{array}$ & $\begin{array}{c}.87^{* *} \\
(5.88)\end{array}$ & $\begin{array}{c}.64 \\
(.82)\end{array}$ & $\begin{array}{c}.85 \\
(1.05)\end{array}$ \\
\hline W2(EFF1-EFF2 & $\begin{array}{l}.30 * * \\
(2.03)\end{array}$ & & $\begin{array}{l}.48^{* *} \\
(2.27)\end{array}$ & $\begin{array}{c}1.36 \\
(1.22)\end{array}$ & $\begin{array}{c}1.41 \\
(1.22)\end{array}$ \\
\hline W1(EFF1) & 、 & $\begin{array}{l}-.55^{* *} \\
(-4.27)\end{array}$ & $\begin{array}{l}-.63 * * \\
(-4.90)\end{array}$ & $\begin{array}{c}-.55 \\
(-.82)\end{array}$ & $\begin{array}{c}-.37 \\
(-.53)\end{array}$ \\
\hline W2(EFF2) & & $\begin{array}{c}-.72 * * \\
(-3.51)\end{array}$ & $\begin{array}{c}-.17 \\
(-.53)\end{array}$ & $\begin{array}{l}1.29 \\
(.79)\end{array}$ & $\begin{array}{l}1.35 \\
(.79)\end{array}$ \\
\hline W2 & $\begin{array}{c}.15^{* *} \\
(2.46)\end{array}$ & $\begin{array}{c}.23 \\
(1.28)\end{array}$ & $\begin{array}{l}-.25 \\
(-.94)\end{array}$ & $\begin{array}{c}-1.00 \\
(-.70)\end{array}$ & $\begin{array}{l}-1.00 \\
(-.67)\end{array}$ \\
\hline OVERLAP & $\begin{array}{c}-.05^{*} \\
(-1.72)\end{array}$ & $\begin{array}{c}-.03 \\
(-.99)\end{array}$ & $\begin{array}{c}-.04 \\
(-1.36)\end{array}$ & $\begin{array}{l}.04 \\
(.25)\end{array}$ & $\begin{array}{c}-.07 \\
(-.43)\end{array}$ \\
\hline STINCOME & $\begin{array}{l}-.22 \\
(-.28)\end{array}$ & $\begin{array}{l}.13 \\
(.19)\end{array}$ & $\begin{array}{l}-.11 \\
(-.17)\end{array}$ & $\begin{array}{l}-8.12^{* *} \\
(-2.32)\end{array}$ & $\begin{array}{c}-11.58 * * \\
(-3.18)\end{array}$ \\
\hline HERF & $\begin{array}{c}-.39 \\
(-1.56)\end{array}$ & $\begin{array}{l}-.05 \\
(-.22)\end{array}$ & $\begin{array}{c}-.17 \\
(-.73)\end{array}$ & $\begin{array}{c}1.63 \\
(1.35)\end{array}$ & $\begin{array}{l}1.20 \\
(.95)\end{array}$ \\
\hline SHARE & $\begin{array}{c}.26 \\
(1.41)\end{array}$ & $\begin{array}{c}.04 \\
(.25)\end{array}$ & $\begin{array}{l}.09 \\
(.58)\end{array}$ & $\begin{array}{c}-.74 \\
(-.90)\end{array}$ & $\begin{array}{l}-.70 \\
(-.82)\end{array}$ \\
\hline RETAIL & $\begin{array}{c}-.20 * * \\
(-2.30)\end{array}$ & $\begin{array}{r}-.15^{*} \\
(-1.93)\end{array}$ & $\begin{array}{c}-.16^{* *} \\
(-2.19)\end{array}$ & $\begin{array}{c}-.50 \\
(-1.29)\end{array}$ & $\begin{array}{c}-.18 \\
(-.44)\end{array}$ \\
\hline SCALE & $\begin{array}{l}-.71 * * \\
(-9.33)\end{array}$ & $\begin{array}{c}-.09 \\
(-.58)\end{array}$ & $\begin{array}{c}-.18 \\
(-1.21)\end{array}$ & $\begin{array}{c}.09 \\
(.11)\end{array}$ & $\begin{array}{l}-.43 \\
(-.52)\end{array}$ \\
\hline Adjusted $\mathrm{R}^{2}$ & .71 & .78 & .80 & .09 & .17 \\
\hline Num. of Obs. & 57 & 57 & 57 & 57 & 57 \\
\hline
\end{tabular}


Table 4: Changes in Prices and Associated Profit Changes from Megamergers

(1981-1989)

\begin{tabular}{lc}
$\begin{array}{lc}\text { Loan and Deposit Price Premiums } \\
\text { Over Peer Group Means: }\end{array}$ & $\mathrm{P}-\mu_{\mathrm{p}}$ \\
\hline & \\
Pre-merger loan premium & 16.64 basis points \\
Post-merger loan premium & 9.83 basis points \\
Increase in loan premium & -6.81 basis points \\
& \\
Pre-merger deposit premium & 72.65 basis points \\
Post-merger deposit premium & 66.41 basis points \\
Increase in deposit premium & -6.24 basis points
\end{tabular}

Change in Profits Due to Changes in Premiums: $\Delta p \bullet q / \pi^{\circ}, \Delta p \bullet q / T A, \Delta p \bullet q / E Q$

Increase in profits/potential profits $\quad 2.77$ basis points

Increase in profits/total assets $\quad-2.31$ basis points

Increase in profits/equity $\quad-83.68$ basis points

Note: None of the figures in this table is statistically significant at the 10 level, two-sided. 
Table 5: Additional Ex Ante Price Variables Used to Predict Market Power Profit Improvements

Variable

Sample Mean

(Range)

V2(P1-P2) $)_{\text {Loan }}:$ wt. difference in pre-merger loan prices (using acquired bank's loan weight).

0.69 basis points (bp)

$(-72.15 \mathrm{bp}, 54.38 \mathrm{bp})$

V2(P1-P2) $)_{\text {Dep }}$ : wt. difference

in pre-merger deposit prices (using

acquired bank's deposit weight).

V1(P1) Loan: wt. pre-merger loan

price of acquiring bank.

(-70.18 bp, 245.46 bp)

V2(P2) $)_{\text {Loan }}$ : wt. pre-merger loan

price of acquired bank.

$1.77 \mathrm{bp}$

(-12.02 bp, 73.95 bp)

V1(P1) $)_{\text {Dep }}$ : wt. pre-merger deposit

price of acquiring bank.

$29.71 \mathrm{bp} * *$

(-106.91 bp, $281.16 \mathrm{bp})$

V2(P2) $)_{\text {Dep }}$ : wt. pre-merger deposit price of acquired bank.

$9.51 \mathrm{bp} *$

(-42.42 bp, $153.94 \mathrm{bp})$

$\mathrm{V}_{\text {Loan }}$ : size of acquiring bank's loans relative to the total assets

of the acquirer plus acquired banks.

$V 1_{\text {Dep }}$ : size of acquiring bank's deposits relative to the total assets

of the acquirer plus acquired banks.

$.33 * *$

$(.12, .60)$

$.32 * *$

$(.07, .72)$

$.13 * *$

$(.01, .36)$

relative to the total assets

of the acquirer plus acquired banks.

V2 ${ }_{\text {Dep }}$ : size of acquired bank's deposits relative to the total assets

of the acquirer plus acquired banks.
$.10 * *$

$(.004, .34)$

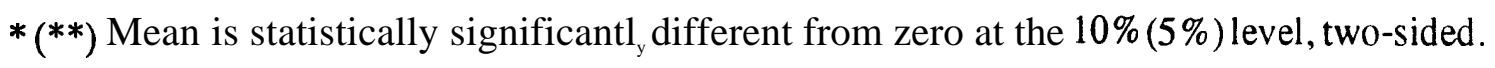


Table 6: Ex Ante Sources of Merger-Related Market Power and Performance Improvements

(1981-1989; t-ratios in parentheses)

\begin{tabular}{|c|c|c|c|}
\hline & $\Delta \mathrm{p}^{\bullet} \mathrm{q} / \pi^{\circ}$ & $\Delta \mathrm{ROA}^{\mathrm{a}}$ & $\triangle \mathrm{ROE}^{\mathrm{a}}$ \\
\hline Intercept & $\begin{array}{c}-0.05 \\
(-1.14)\end{array}$ & $\begin{array}{c}0.08 \\
(0.08)\end{array}$ & $\begin{array}{c}0.22 \\
(0.23)\end{array}$ \\
\hline W2(EFF1-EFF2) & $\begin{array}{l}0.05 \\
(0.77)\end{array}$ & $\begin{array}{c}0.07 \\
(0.05)\end{array}$ & $\begin{array}{c}-0.56 \\
(-0.38)\end{array}$ \\
\hline W1(EFF1) & $\begin{array}{c}-0.001 \\
(-0.03)\end{array}$ & $\begin{array}{c}-0.001 \\
(-0.001)\end{array}$ & $\begin{array}{c}0.28 \\
(0.28)\end{array}$ \\
\hline W2(EFF2) & $\begin{array}{c}0.08 \\
(0.87)\end{array}$ & $\begin{array}{c}0.25 \\
(0.12)\end{array}$ & $\begin{array}{c}-0.76 \\
(-0.35)\end{array}$ \\
\hline W2 & $\begin{array}{c}-0.04 \\
(-0.46)\end{array}$ & $\begin{array}{c}0.43 \\
(0.23)\end{array}$ & $\begin{array}{c}1.26 \\
(0.65)\end{array}$ \\
\hline $\mathrm{V} 2(\mathrm{P} 1-\mathrm{P} 2)_{\text {Loan }}$ & $\begin{array}{c}-5.99 * \\
(-1.86)\end{array}$ & $\begin{array}{c}-141.58 * \\
(-1.97)\end{array}$ & $\begin{array}{l}-98.53 \\
(-1.32)\end{array}$ \\
\hline$-\mathrm{V} 2(\mathrm{P} 1-\mathrm{P} 2)_{\mathrm{Dep}}$ & $\begin{array}{l}-1.63 \\
(-1.09)\end{array}$ & $\begin{array}{c}-4.03 \\
(-0.12)\end{array}$ & $\begin{array}{l}-13.79 \\
(-0.39)\end{array}$ \\
\hline $\mathrm{V} 1(\mathrm{P} 1)_{\text {Loan }}$ & $\begin{array}{c}0.39 \\
(0.49)\end{array}$ & $\begin{array}{l}27.28 \\
(1.55)\end{array}$ & $\begin{array}{l}16.78 \\
(0.92)\end{array}$ \\
\hline $\mathrm{V} 2(\mathrm{P} 2)_{\text {Loan }}$ & $\begin{array}{l}-9.96^{* *} \\
(-2.50)\end{array}$ & $\begin{array}{c}-263.74 * * \\
(-2.96)\end{array}$ & $\begin{array}{c}-223.39 * * \\
(-2.42)\end{array}$ \\
\hline$-\mathrm{V} 1(\mathrm{P} 1)_{\mathrm{Dep}}$ & $\begin{array}{l}-0.21 \\
(0.30)\end{array}$ & $\begin{array}{c}2.69 \\
(0.17)\end{array}$ & $\begin{array}{c}9.02 \\
(0.56)\end{array}$ \\
\hline$-\mathrm{V} 2(\mathrm{P} 2)_{\mathrm{Dep}}$ & $\begin{array}{r}-1.95^{*} \\
(-1.74)\end{array}$ & $\begin{array}{c}7.23 \\
(0.29)\end{array}$ & $\begin{array}{c}-6.14 \\
(-0.24)\end{array}$ \\
\hline $\mathrm{V} 1_{\text {Loan }}$ & $\begin{array}{c}0.06 \\
(1.49)\end{array}$ & $\begin{array}{c}1.23 \\
(1.37)\end{array}$ & $\begin{array}{c}1.29 \\
(1.39)\end{array}$ \\
\hline $\mathrm{V} 1_{\text {Dep }}$ & $\begin{array}{c}-0.01 \\
(-0.25)\end{array}$ & $\begin{array}{c}-0.31 \\
(-0.43)\end{array}$ & $\begin{array}{c}-0.56 \\
(-0.77)\end{array}$ \\
\hline
\end{tabular}

(Parameters continued on next page) 


\section{Table 6 (continued)}

\begin{tabular}{|c|c|c|c|}
\hline & $\Delta \mathrm{p} \bullet \mathrm{q} / \pi^{\circ}$ & $\triangle \mathrm{ROA}^{\mathrm{a}}$ & $\triangle \mathrm{ROE}^{\mathrm{a}}$ \\
\hline$V 2_{\text {Loan }}$ & $\begin{array}{c}0.03 \\
(0.34)\end{array}$ & $\begin{array}{c}1.98 \\
(1.03)\end{array}$ & $\begin{array}{c}2.32 \\
(1.16)\end{array}$ \\
\hline $\mathrm{V} 2_{\text {Dep }}$ & $\begin{array}{c}0.02 \\
(0.32)\end{array}$ & $\begin{array}{c}0.02 \\
(0.02)\end{array}$ & $\begin{array}{c}-0.47 \\
(-0.29)\end{array}$ \\
\hline OVERLAP & $\begin{array}{c}-0.004 \\
(-0.51)\end{array}$ & $\begin{array}{c}-0.10 \\
(-0.63)\end{array}$ & $\begin{array}{c}-0.18 \\
(-1.10)\end{array}$ \\
\hline STINCOME & $\begin{array}{c}0.03 \\
(0.21)\end{array}$ & $\begin{array}{c}-4.26 \\
(-1.16)\end{array}$ & $\begin{array}{c}-7.65^{*} \\
(-2.00)\end{array}$ \\
\hline HERF & $\begin{array}{c}-0.09 \\
(-1.36)\end{array}$ & $\begin{array}{c}-0.99 \\
(-0.68)\end{array}$ & $\begin{array}{c}-1.19 \\
(-0.79)\end{array}$ \\
\hline SHARE & $\begin{array}{c}0.09 * \\
(1.77)\end{array}$ & $\begin{array}{c}1.12 \\
(1.03)\end{array}$ & $\begin{array}{c}1.14 \\
(1.02)\end{array}$ \\
\hline RETAIL & $\begin{array}{c}0.05 \\
(1.56)\end{array}$ & $\begin{array}{c}-0.40 \\
(-0.52)\end{array}$ & $\begin{array}{c}-0.41 \\
(-0.51)\end{array}$ \\
\hline SCALE & $\begin{array}{c}-0.03 \\
(-0.52)\end{array}$ & $\begin{array}{c}-0.47 \\
(-0.43)\end{array}$ & $\begin{array}{c}-0.68 \\
(-0.61)\end{array}$ \\
\hline $\begin{array}{l}\text { Adjusted } \mathrm{R}^{2} \\
\text { Num. of Obs. }\end{array}$ & $\begin{array}{r}0.31 \\
57\end{array}$ & $\begin{array}{r}0.16 \\
57\end{array}$ & $\begin{array}{r}0.24 \\
57\end{array}$ \\
\hline
\end{tabular}

${ }^{*}(* *)$ Statistically significantly different from zero at the $10 \%(5 \%)$ level, two-sided. 
Table A1: Variables Employed in the Standard and Nonstandard Profit Functions

Variable

Sample Means (1981-1989)

$\pi: \quad$ Total Variable Profits

$\mathrm{p}_{1}$ : $\quad$ Price of Loans (Standard function only)

$\mathrm{p}_{2}: \quad$ Price of Securities (Standard function only)

$\mathrm{p}_{3}$ : $\quad$ Price of Deposits

$\mathrm{p}_{\mathbf{4}}: \quad$ Price of Labor

$\mathbf{z}_{1}: \quad$ Equity Capital (book value)

$\mathrm{z}_{2}$ : Loans (Nonstandard function only)

$\mathbf{z}_{3}$ : Securities (Nonstandard function only)

Number of Observations
$\$ 308.8$ million

0.121

0.089

0.046

$\$ 23,276$

\$365.7 million

$\$ 3,394.8$ million

$\$ 2,187.8$ million

2944

Notes:

Financial variables are reported in 1982 dollars in this table. However, for computational convenience, these variables are measured in thousands of 1982 dollars, except equity capital which is measured in tens of thousands of 1982 dollars.

The prices of outputs $\left(\mathrm{p}_{1}, \mathrm{p}_{2}\right)$ are included only in the standard profit function and the quantities of the outputs $\left(\mathbf{z}_{2}, \mathbf{z}_{3}\right)$ are included only in the nonstandard profit function. 
Table A2: Standard Profit Function Model

(t-statistics in parentheses)

Dependent Variable $\pi / \mathrm{p}_{4} \quad \pi / \mathrm{p}_{4} \quad$ (Continued)

\begin{tabular}{|c|c|c|c|}
\hline$\alpha_{1}$ & $\begin{array}{c}-524.093 \\
(-12.51)\end{array}$ & $\phi_{33}$ & 16.492 \\
\hline$\alpha_{3}$ & $\begin{array}{c}503.506 \\
(9.73)\end{array}$ & $\tau_{1}$ & $\begin{array}{r}1.935 \\
(19.36)\end{array}$ \\
\hline$\alpha_{3}$ & $\begin{array}{c}375.023 \\
(6.91)\end{array}$ & $\tau_{2}$ & $\begin{array}{c}-0.882 \\
(-6.71)\end{array}$ \\
\hline$\alpha_{4}$ & $\begin{array}{r}2578.34 \\
(13.11)\end{array}$ & $\tau_{3}$ & $\begin{array}{c}1.346 \\
(4.58)\end{array}$ \\
\hline$\phi_{11}$ & 27.585 & $\beta_{1}$ & $\begin{array}{c}-49.761 \\
(-43.16)\end{array}$ \\
\hline$\phi_{12}$ & -11.875 & $\sigma_{11}$ & $\begin{array}{r}0.010 \\
(6.79)\end{array}$ \\
\hline$\phi_{13}$ & 9.391 & $\gamma_{21}$ & $\begin{array}{r}40.133 \\
(160.74)\end{array}$ \\
\hline$\phi_{21}$ & -11.875 & $\gamma_{21}$ & $\begin{array}{r}21.559 \\
(122.53)\end{array}$ \\
\hline$\phi_{22}$ & 60.230 & $\gamma_{31}$ & $\begin{array}{r}-91.044 \\
(-128.05)\end{array}$ \\
\hline$\phi_{23}$ & 23.027 & & \\
\hline$\phi_{31}$ & 9.391 & & \\
\hline$\phi_{32}$ & 23.027 & & \\
\hline
\end{tabular}

$\begin{array}{ll}\text { Adjusted } R^{2} & 0.9245 \\ \text { Num. of Obs. } & 2944\end{array}$

Note: t-statistics are not available for the $\phi_{\mathrm{ij}}$ estimates because they are derived from the "closest" (in the sense of minimizing the Euclidean norm of the difference) positive semidefinite matrix to the estimated $\phi$ matrix. 
Table A3: Nonstandard Profit Model: Output Prices Replaced by Output Quantities

(t-statistics in parentheses)

Dependent Variable $\pi / \mathrm{p}_{4} \quad \mathrm{~T} / \mathrm{pal}$ (Continued)

\begin{tabular}{|c|c|c|c|}
\hline$\alpha_{3}$ & $\begin{array}{l}-8.845 \text { E } 5 \\
(-2.69)\end{array}$ & $\sigma_{33}$ & $\begin{array}{l}-2.328 \mathrm{E}-10 \\
(-8.41)\end{array}$ \\
\hline$\alpha_{4}$ & $\begin{array}{l}3.524 \text { E } 3 \\
(8.37)\end{array}$ & $\gamma_{31}$ & $\begin{array}{l}-2.859 \text { E } 3 \\
(0.31)\end{array}$ \\
\hline$\sigma_{33}$ & $\begin{array}{l}2.812 \text { E } 8 \\
(2.56)\end{array}$ & $\gamma_{32}$ & $\begin{array}{r}-0.156 \\
(-1.80)\end{array}$ \\
\hline$\beta_{1}$ & $\begin{array}{c}329.776 \\
(11.65)\end{array}$ & $\gamma_{33}$ & $\begin{array}{l}0.340 \\
(3.96)\end{array}$ \\
\hline$\beta_{1}$ & $\begin{array}{l}9.387 \mathrm{E}-4 \\
(3.19)\end{array}$ & & \\
\hline$\beta_{3}$ & $\begin{array}{l}-1.976 \text { E-3 } \\
(-6.88)\end{array}$ & & \\
\hline$\sigma_{11}$ & $\begin{array}{r}-1.229 \\
(-6.10)\end{array}$ & & \\
\hline$\sigma_{12}$ & $\begin{array}{l}2.147 \mathrm{E}-5 \\
(5.54)\end{array}$ & & \\
\hline$\sigma_{13}$ & $\begin{array}{l}-4.787 \mathrm{E}-7 \\
(-0.21)\end{array}$ & & \\
\hline$\sigma_{22}$ & $\begin{array}{l}-1.435 \mathrm{E}-10 \\
(-8.53)\end{array}$ & & \\
\hline$\sigma_{23}$ & $\begin{array}{l}2.474 \mathrm{E}-10 \\
(7.95)\end{array}$ & & \\
\hline & Adjusted $\mathbf{R}^{2}$ & & 0.9166 \\
\hline
\end{tabular}

Num. of Obs. 2994

Note: We treated the outputs as though they were fixed netputs, so loans and securities are measured by $z_{2}$ and $\mathbf{z}_{3}$, respectively. The $\phi_{33}$ estimate is already positive semi-definite, so it did not have to be adjusted. 